\title{
Anna Francisca de Bruyns (1604/5-1656), Artist, Wife and Mother: a Contextual Approach to Her Forgotten Artistic Career
}

\author{
Katlijne Van der Stighelen
}

In a sketchbook preserved in the Print Room of the Royal Museum of Fine Arts in Brussels is a drawing by Anna Francisca de Bruyns. This small selfportrait, drawn in black ink on a sheet measuring $150 \times 90 \mathrm{~mm}$, almost seems to present a concise biography. At the bottom of the sheet, scrawled letters resemble first words, Mon mamam $d a d a,{ }^{1}$ as though De Bruyns was drawing while a child sat on her knee. Unlike the famous Judith Leyster of Haarlem (1609-166o), De Bruyns continued her artistic practice after her marriage. ${ }^{2}$ This raises the question of whether women in general largely abandoned their artistic ambitions once married. In her dissertation on the aptitude of the female mind for science and letters, published in 1641, the learned Anna Maria van Schurman (1607-1678) even argued that educated women should not be distracted by domestic obligations; instead, they should employ servants and never marry. ${ }^{3}$ This assertion notwithstanding, it is noteworthy that during the sixteenth century numerous Netherlandish female artists were married. Agnes van den Bossche (c. 1440-after 1502), Susanna Horenbout

1 Sketchbook of Anna Francisca de Bruyns, inv. no. 6507, fol. 40, black ink on paper, $195 \times 165$ $\mathrm{mm}$, Brussels Royal Library Print Room. The sketchbook was first mentioned in, Michel Benisovich, "Biographie d'Anne Françoise de Bruyns, peintre, écrite par Jacques Ignace Bullarts son fils," Oud-Holland 68 (1953): 179-182. In 1983, Eliane De Wilde, the then Director of the Royal Museum of Fine Arts in Brussels, published an entry on De Bruyns in Nationaal Biografisch Woordenboek, x, Brussels, 1983, col. 70-73. In 1997 a master thesis was written under my supervision: Mieke Ackx, Anne Françoise de Bruyns (1604-1656) '(her)ontdekt': een monografische studie van 'Nostri Miracula Belga' met kritische oeuvre-catalogus, KU Leuven, Leuven, 1997. See also: Jacques Toussaint (ed.), Portrait en Namurois (Namur: Société Archéologique de Namur, 2002), 42.

2 See: James E. Welu \& Pieter Biesboer, Judith Leyster. Schilderes in een mannenwereld, exhibition cat. (Worcester, Zwolle: Frans Halsmuseum Haarlem-Worcester Art Museum, 1993), 23-24.

3 Caroline van Eck, "The First Dutch Feminist Tract? Anna Maria van Schurman's discussion of women's aptitude for the study of arts and sciences," in Choosing the Better Part. Anna Maria van Schurman (1607-1678), ed. Mirjam de Baar, Machteld Löwensteyn a. o. (Dordecht-BostonLondon: Kluwer Academic Publishers, 1996), 44-46. 


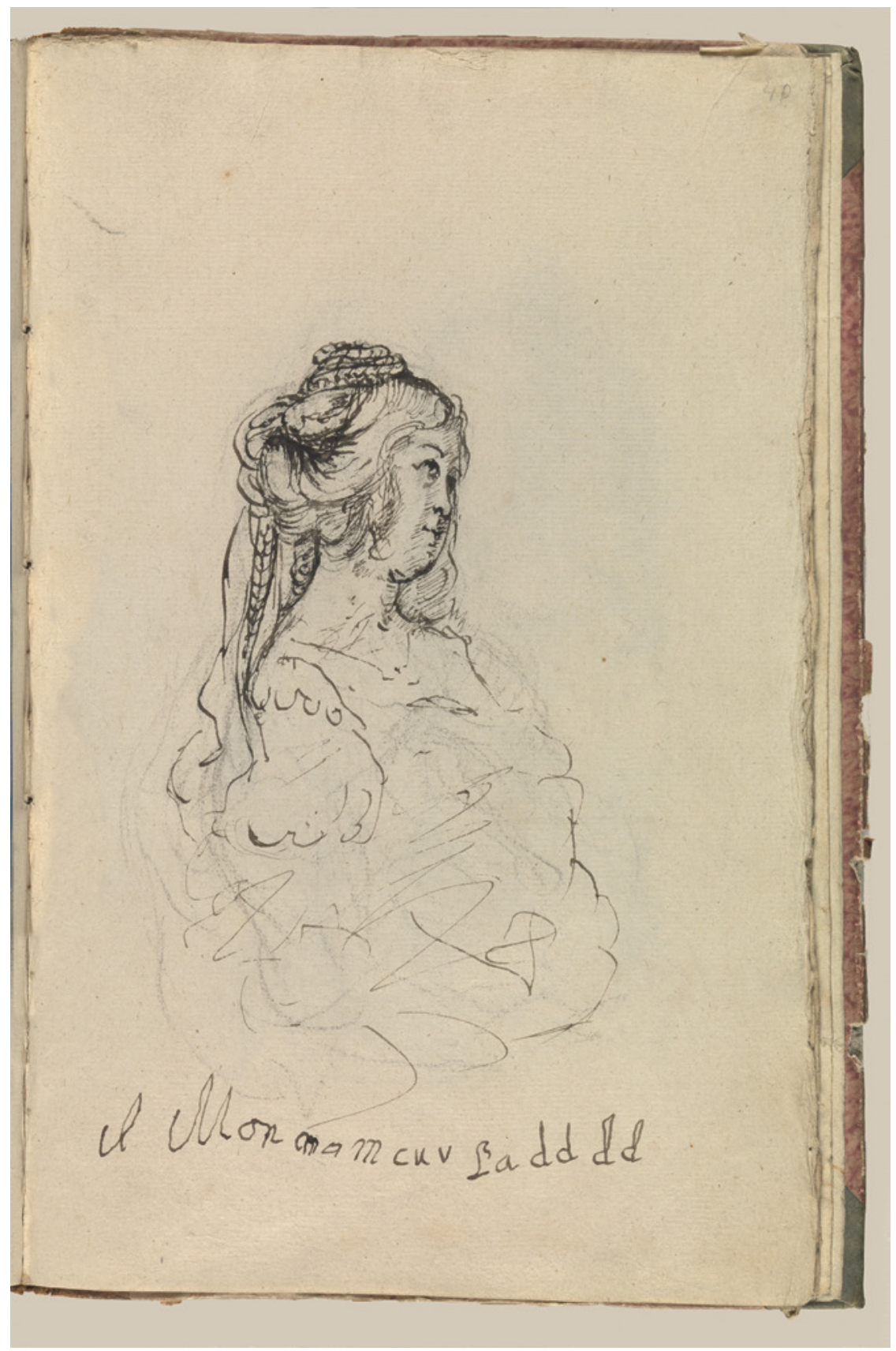

FIGURE 6.1 Anna Francisca de Bruyns, Self-Portrait with inscription 'Mon maman dada', sketchbook, Department of Prints and Drawings, 6507/40r ${ }^{\circ}$, Royal Museum of Fine Arts, Brussels, photo: J. Geleyns - Ro scan 
(active c. 1520-1540), Levina Teerlinck (c. 150-1576), Mechtelt van Lichtenberg toe Boecop (c. 1520-1598) and Catharina van Hemessen (1528-after 1581) all were married even as they actively pursued their art. Moreover, this tradition continued throughout the seventeenth century. Such artists as Clara Peeters (c. 1580-1657), Margaretha de Heer (before 1603-before 1665), Maria de Grebber (c. 1602-1680) and Susanna van Steenwijck-Gaspoel (c. 1610-after 1653) all seem to have continued their artistic activities while married. ${ }^{4}$ However, many women artists, mostly belonging to the upper middle class, remained single. ${ }^{5}$ Magdalena de Passe (1587-1643), Geertrui van Veen (1602-1643), Jacoba van Veen (c. 1639-after 1675), Catharina Pepijn (1619-1688) and Michaelina Wautier (1614-1689), to mention just a few, never married. ${ }^{6}$ During the sixteenth and seventeenth centuries it was nearly impossible to be formally initiated into an artistic profession as a woman. Lacking both tradition and faith in women's talent, Netherlandish guilds only rarely registered girls or young women as pupils unless they were born into families of artists and already familiar with a craft. Even for middle class women, training in workshops mainly attended by men seems to have been viewed as unacceptable. Educated women with artistic ambition whom came from good families generally received their artistic training from private teachers who tutored them in the women's homes. Because such training and practice occurred at home, these women artists have remained invisible. ${ }^{7}$ Nearly no cultivated women had direct access to the entourage of professional painters, and this precluded their becoming official artists. It is consequently difficult to uncover the experiences of female

4 Because of the problem of dating their work it is extremely difficult to confirm post-marriage artistic activity. Thanks to the report of Anna Francisca's son we can say with certainty that it is the case with De Bruyns, which makes her case-study all the more interesting.

5 On Clara Peeters, see: Alejandro Vergara (ed.), De kunst van Clara Peeters, exhibition cat. Antwerp: Rockoxhuis and Mardrid: Prado Museum (Antwerp: Rockoxhuis, 2016), 13; Jean Bastiaensen, "Finding Clara: Establishing the Biographical Details of Clara Peeters (ca. 1587 -after 1636)" in Boletin del Museo del Prado, xxxiv, número 52, 2016, 17-31. See also: Judith M. Bennett and Amy M. Froide (eds.), Singlewomen in the European Past 1250-180o (Philadelphia: University of Pennsylvania Press, 1998).

6 For an overview of women-artists active in The Netherlands during the sixteenth and seventeenth centuries, see: Katlijne Van der Stighelen \& Mirjam Westen, 'Elck zijn waerom. Vrouwelijke kunstenaars in Belgie en Nederland 1500-1950, exhibition cat. Antwerp: Royal Museum of Fine Arts and Arnhem, Gent: Museum of Modern Art (Brussels: Ludion, 2000), 126-202. Although it remains unclear whether all these married women continued art practice after their marriage there is no archival evidence that they did not.

7 See:Elizabeth Honig, “'Artistieke' vrouwen in de Noordelijke Nederlanden in de vroegmoderne tijd," in Katlijne Van der Stighelen \& Mirjam Westen, "Elck zijn waerom," 43-57. 


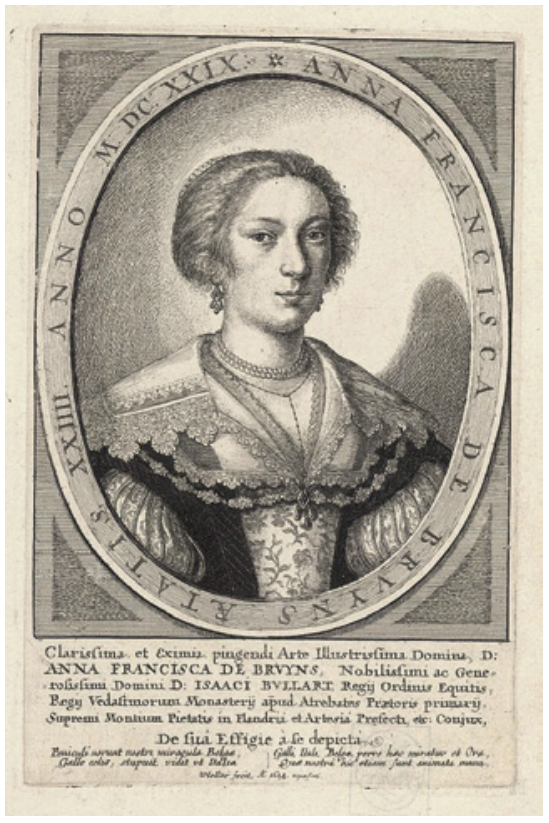

FIGURE 6.2

Wenceslas Hollar after Anna Francisca de Bruyns', Self-Portrait, engraving after the prototype of 1629, 1648, MS. 819, f. 425, Bibliothèque Municipale, Lille

artists. Broadly speaking, only scarce biographical information is available and few works can be identified because of the lack of signatures.

De Bruyns is an exception to the rule. She was born into an upper middleclass family and raised by outstanding court artists who happened to be her relatives. Compared to early modern women artists in general, much is known about Anna Francisca de Bruyns. Her son left a unique and never before published autobiographical document that allows a glimpse of her life and career. The main objective of this article is to determine how De Bruyns balanced her artistic drive with her domestic responsibilities, including motherhood. To do so, it is first imperative, however difficult, to present an overview of her paintings and drawings in order to analyse her particular iconography and style.

An introduction to the artist herself is in order, and for that we need to examine her familial connections. Anna Francisca de Bruyns was born in 1604 in Morialmé (near Dinant, in the province of Namur) where her father, Cornille de Bruyns, was bailiff. In 1633 at the latest he moved to Mons, becoming the superintendent of the Bergh van Bermherticheyt or public pawnshop, an 


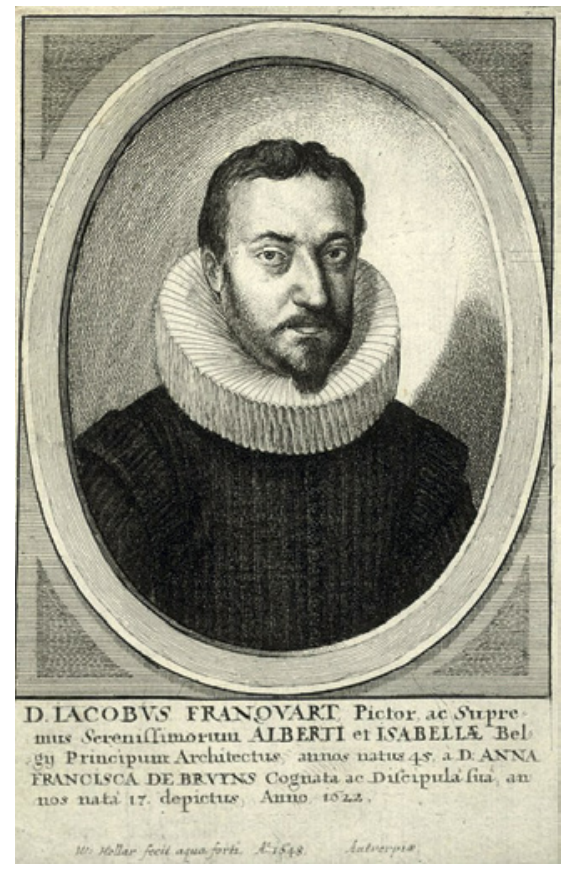

FIGURE 6.3

Anna Francisca de Bruyns, Portrait of Jacques Francart, 1622, MS. 819, f. 399, Bibliothèque Municipale, Lille

institution founded several years earlier by Wenceslas Cobergher (1557/611634). 8 One of Anna Francisca's cousins was Jacques Francart (Rome, 1583Brussels, 1654). Twenty-two years her senior, he would play an important part in her training. ${ }^{9}$ In 1613, when Anna Francisca was nine years old, Francart was appointed court painter to the Archdukes Albert and Isabella. On 27 July 1622, he became Royal Architect-Engineer to Philip IV of Spain. ${ }^{10}$ Francart subsequently also took over many of Cobergher's responsibilities. ${ }^{11}$

Both Francart and Cobergher spent many years in Italy. They met in 1591 in Naples, where Cobergher was chiefly occupied as a painter. In 1597 Cobergher

8 See: Paul Soetaert, "De Bergen van Barmhartigheid in de Spaanse, Oostenrijkse en de Franse Nederlanden (1618-1795)," Historische Uitgaven, no. 67 (1986): 89-9o.

9 On Francart's role as a court painter and architect, see: Annemie De Vos, Jacques Francart. Premier Livre d'Architecture (1617). Studie van een Zuid-Nederlands modelboek met poortgebouwen, (Brussels: Académie royale des Sciences, des Lettres et des BeauxArts de Belgique, 1998), especially 17-30. For more biographical information: Annemie de Vos, "Hofarchitect Jacques Francart en de Brusselse jezuïetenkerk. Tussen traditie en vernieuwing," De zeventiende eeuw 14 (1998): 65-80.

10 Annemie De Vos, Jacques Francart, 20-21, 30.

11 On the artistic relationship between Cobergher and Francart, see: Tine Meganck, De kerkelijke architectuur van Wensel Cobergher (1557/61-1634) in het licht van zijn verblijf in Rome (Brussels: Paleis der Academiën, 1998), 31, 80-96. 
moved to Rome, where, after the death of his first wife, Michaella Cerf, he married Susanna Francart, Jacques's sister and thus Anna Francisca's cousin, in the Church of San Lorenzo on 20 November 1599. The groom was thirtyeight, the bride just sixteen..$^{12}$ Cobergher remained in Italy until 1605 , when he entered the service of the Archdukes. They paid him three times as much as they would Rubens, which gives us some idea of his prestige. Cobergher quickly became a leading engineer, architect, painter and numismatist. He was the architect of the Basilica of Our Lady in Scherpenheuvel (Montaigu in French), a project that was begun by the Archdukes in 1609 and culminated in the consecration of the basilica in $1627 .^{13}$ Anthony van Dyck included Cobergher's portrait in his Iconography, a series of engraved portraits of the most eminent contemporary noblemen, intellectuals and artists. ${ }^{14}$

Endogamous alliances continued from one generation to the next. One of Cobergher's daughters, Cécile, married André de Bruyns, a relative of Anna Francisca's father, so that Cécile was simultaneously Anna Francisca's second cousin and aunt. The couple lived in Mons, where André held the office of 'Mayeur de la ville' (mayor or burgomaster) between 1640 and $1650 .{ }^{15}$

\section{$2 \quad$ An Author as a Husband}

Thus, from the day she was born, Anna Francisca's parentage and family contacts gave her unusual opportunities to develop her artistic talent. As will become evident, she seized these opportunities with both hands. Three rich sources enable an investigation of the particularities of her life.

First among them is Isaac Bullart's Académie des Sciences et des Arts, published in 1682. Bullart (Rotterdam, 1599-Arras, 1672) was a Dutch-born writer who had studied at the Jesuit College in Bordeaux. ${ }^{16} \mathrm{He}$ and Anna Francisca married in 1628 , when she was twenty-four. He spent thirty years collecting material for the two-volume book, which contains 279 biographies of

12 See: Tine Meganck, kerkelijke architectuur, 20-23.

13 See: ibid., $5^{2-94}$.

14 See: Marie Mauquoy-Hendrickx, L'iconographie d'Antoine van Dyck: catalogue raisonné, vol. 1, 2nd ed. (Brussels: Paleis der Academiën, 1956), 150, Nr. 77.

15 See:P. De Decker,Études historiques et critiques sur les Monts-de-Piété en Belgique (Brussels, 1844), 130-131. The names of eight children of Cobergher (Cathérine, Madeleine, Charles, Cécile, Augustin, Jacques, Marie-Thérèse and Marie Émérence) are registered as heirs of their father's goods. The inventory was made up c. 1645. See: Léopold Devillers, Notice sur le dépôt des archives de l'État de Mons (Mons, 1871), 292.

16 See also:J. N. Paquot, Mémoires pour servir à l'histoire Littéraire des Dix-Sept Provinces des Pays-Bas, vol. 3 (Leuven, 1770), 648-650. 


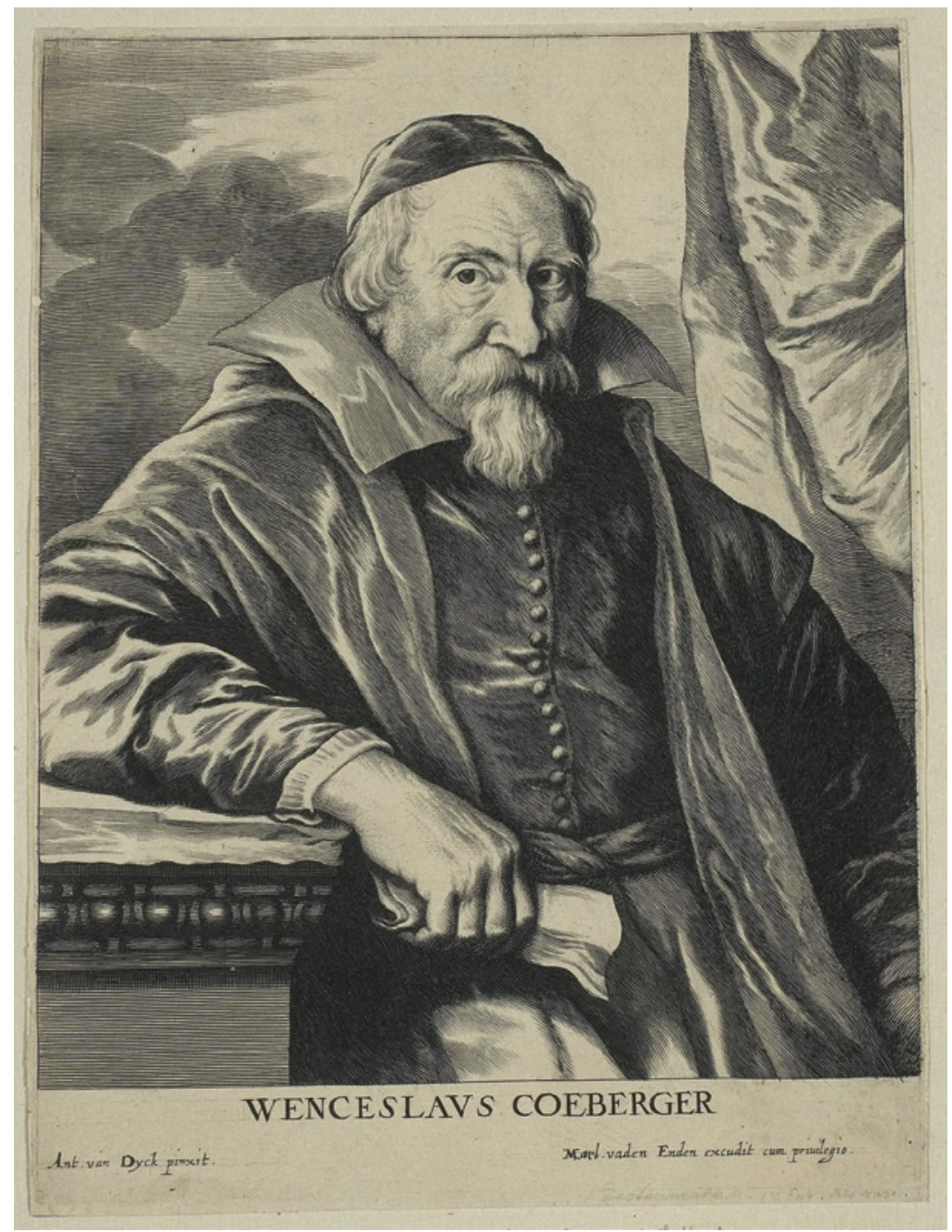

FIGURE 6.4 Lucas Vorsterman after Anthony van Dyck, Portrait of Wenceslas Cobergher, c. 1634-1644, National Gallery of Canada, Ottawa

scholars and artists and is one of the most important biographical compendia of the seventeenth century. In 1647 Anne of Austria, Regent of France for her son Louis XIV, made Bullart a Chevalier de l'Ordre de Saint-Michel (Knight of the Order of St. Michael), evidence of the high regard in which he was held. ${ }^{17}$ In a

17 For a full overview of Bullart's intellectual activities, see: Anne Delvingt, "L'Académie des sciences et des arts (1682) d'Isaac Bullart et les 'Peintres illustres du Pays-Bas \& autres en deçà des Monts," in L'histoire de l'histoire de l'art septentrional au XVII e siècle, Collection 


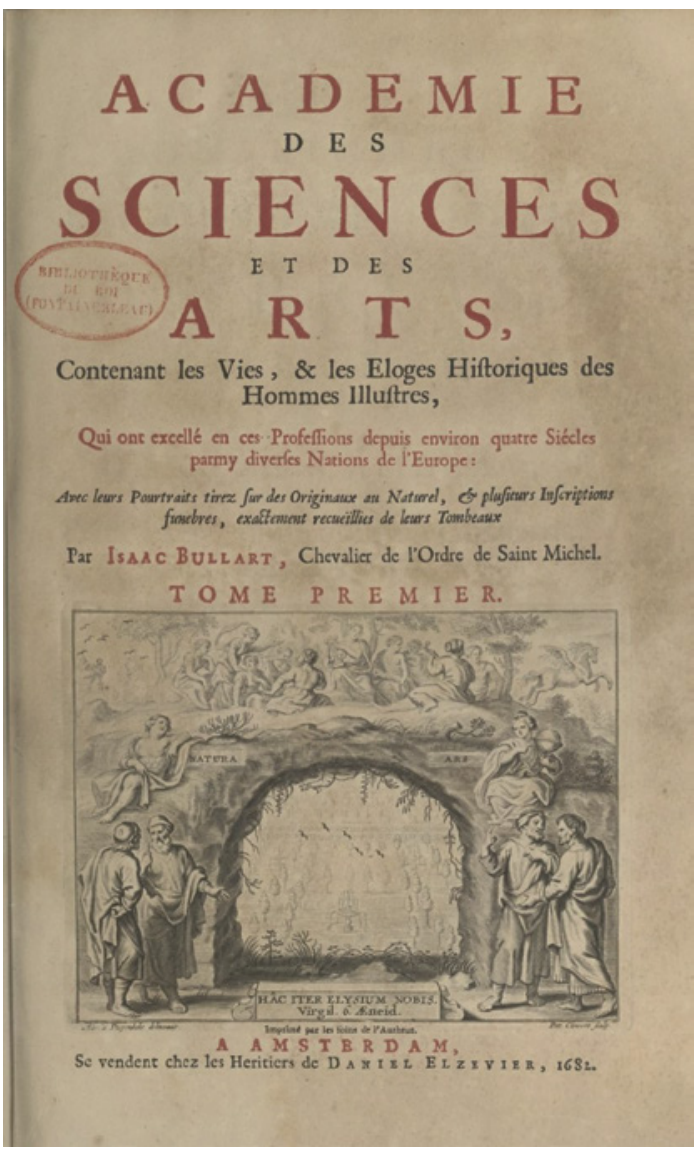

FIGURE 6.5

Title page of Isaac Bullart, Académie des sciences et des arts, contenant les vies et les éloges historiques des hommes illustres qui ont excellé en ces professions depuis environ quatre siècles parmy diverses nations de l'Europe, avec leurs portraits tiréz sur les originaux au naturel et plusieurs inscriptions funèbres, exactement recueillies de leurs tombeaux par Isaac Bullart, volume 1, Amsterdam, 1682

portrait painted by Isaac and Anna's son, Jacques Ignace, in 1648, Bullart wears the insignia of the Order on his breast. The second critical source is a threepart manuscript of Bullart's text in the Municipal Library in Lille, in which Jacques Ignace, who published his father's Académie, had made all manner of notes. These are not included in the printed version and, indeed, have never been published in any form. ${ }^{18}$ Finally, there is Anna Francisca de Bruyns's

Théories de l'art/ Art Theory (1400-180o), ed. Michèle-Caroline Heck (Turnhout: Brepols, 2009), 67-78.

18 Michèle-Caroline Heck, L'histoire, 70. See also: A. J. G. Le Glay, Catalogue descriptif des manuscrits de la Bibliothèque de Lille (Lille, 1848), 274; Arthur Dinaux, Achives historiques et littéraires du Nord de la France, Valenciennes, vol. 3 (1852), 153-154. From the early fifties onwards Bullart was apparently unjustly the subject of several trials and suffered from financial problems. Going through his biography is not possible within this article although it goes without saying that Anna Francisca de Bruyns suffered from the 


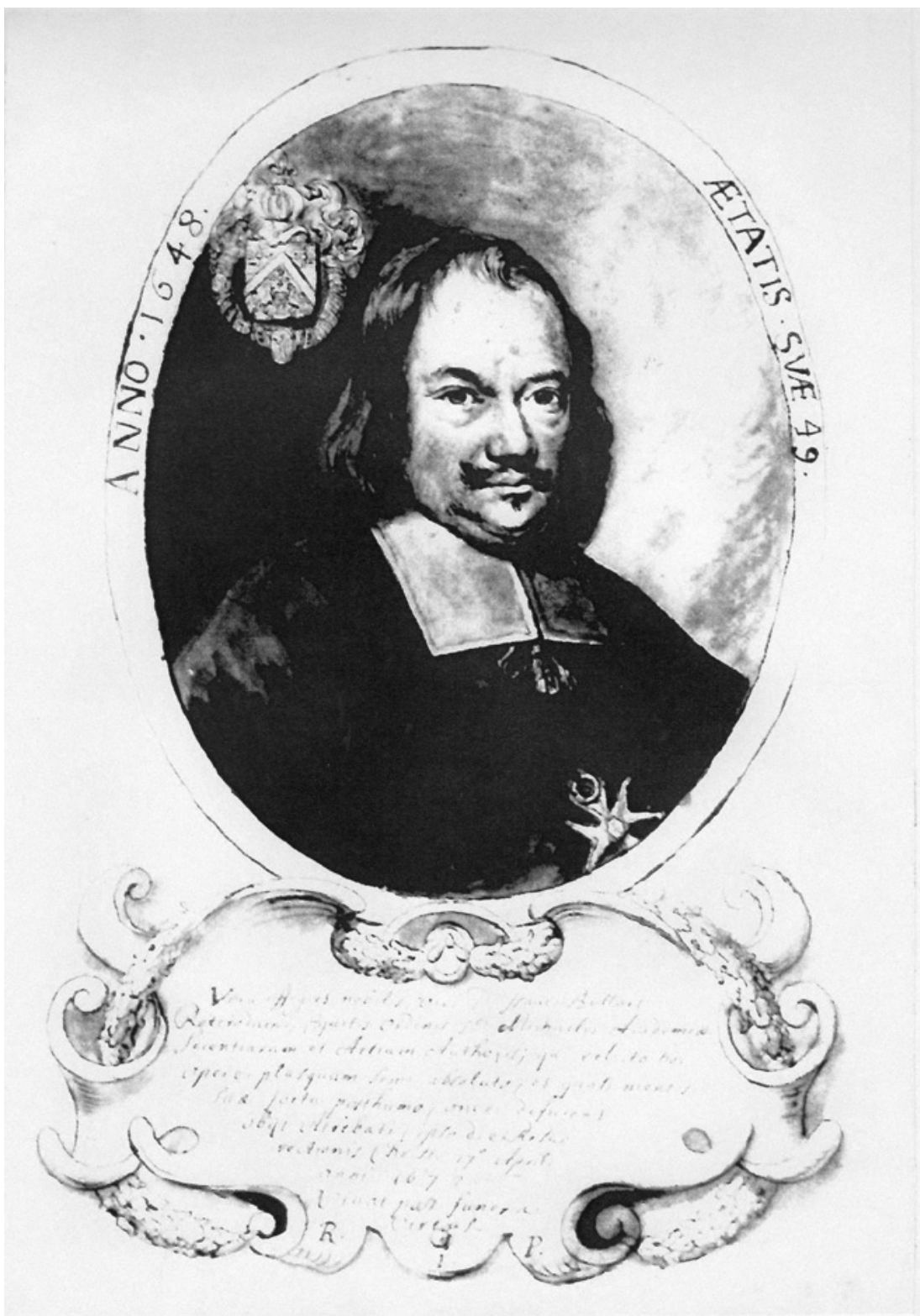

FIG URE 6.6 Jacques Ignace Bullart after Anna Francisca de Bruyns, Portrait of Isaac Bullart, 1648(?), MS. 819, f. 421, Bibliothèque Municipale, Lille 
sketchbook, preserved in the Print Room of the Royal Museum of Fine Arts in Brussels. It contains fifty-six pasted-in drawings and sketches, all but a handful by the artist herself. It came into the possession of her son, Jacques Ignace, who added an abridged biography with interesting supplementary details. ${ }^{19}$

A Son as an Admirer

A few extremely relevant snippets of biographical information can be gleaned from the Académie des Sciences et des Arts, published by Jacques Ignace in 1682, ten years after his father's death. ${ }^{20}$ Anna Francisca de Bruyns does not have a separate entry of her own and is mentioned only in the biography of her cousin and mentor Jacques Francart. However, Jacques Ignace appended an extra paragraph to this entry. His authorship is clear from the fact that he describes Anna Francisca as ma mère. He refers to her by her maiden name, notes her association with Francart, and cites an important fact:

It is from [Francart] that Anna Francisca de Bruyns, his niece and my mother, learned how to paint. After he introduced her into this wonderful art, he presented her to the Archduchess Isabella to whom, as a mark of her esteem, she offered the Fifteen Mysteries of the Rosary in miniature. Isabella thought so highly of the series that she sent it to Pope Paul v because such a gift would appeal to his curiosity. ${ }^{21}$

worsening of her family too. Because her works are not exactly datable it is impossible to ensure whether there was a relation between her artistic output and less advantageous social situation. See: Paul Huchette, Lombards et Mont-de-Piété à Arras, Arras (1914), $63-89$.

19 See note 1.

20 Isaac Bullart, Académie des sciences et des arts, contenant les vies et les éloges historiques des hommes illustres qui ont excellé en ces professions depuis environ quatre siècles parmy diverses nations de l'Europe, avec leurs portraits tiréz sur les originaux au naturel et plusieurs inscriptions funèbres, exactement recueillies de leurs tombeaux par Isaac Bullart, 2 volumes (Amsterdam-Brussels-Paris, 1682). A second edition was published in Brussels in 1695.

21 Isaac Bullart, II, 484. This quote is, apart from the engraved portrait of Francart after a portrait by De Bruyns on p. 483 , the only reference to Anna Francisca de Bruyns. Originally in French: "C'est de luy [Francart] qu'Anne Françoise de Bruyns, ma mère \& sa cousine, a apris la Peinture. Aprés qu'il luy eut enseigné ce bel art, il la fit connoistre à l'Infante Isabelle; qui pour marque de son estime voulut avoir les quinze Mysteres du Rosaire peints de sa main en petit; lesquels elle envoya au Pape Paul V. comme un present digne de la curiosité de ce grand Pontife." 
Though brief, these few lines contain essential information: Anna Francisca was taught by Francart and was introduced by him to the Brussels court. The Infanta Isabella thought so highly of her that she bought (or commissioned) from her fifteen small paintings of the Mysteries of the Rosary, which she subsequently sent as a gift to Pope Paulv.

Jacques Ignace Bullart was clearly convinced of the importance of this information about his mother, since he wrote four pages about her in the Lille manuscript, with many additional details. It is not impossible that he intended this material to be inserted in a later edition of his father's publication, for in his first sentence he writes:

Because the paintings by Anna Françoise de Bruyns are highly valued, she deserves to be included by me in this "Academy," not through hollow flattering words but because the memory of a good and virtuous mother who raised and nourished me tenderly does not permit me to be ungrateful or fail to mention her fame as an artist.

Yet at the same time, he clearly realized that he ought not to be overly lavish in his praise, given that she was his mother: "A child should talk soberly about his mother and venerate her with modesty." To demonstrate that he is as objective about her as he is about anyone else, he immediately adds that her work (son industrie) is in no way comparable to that of "the great Geniuses of Painting who are celebrated in this book" (ces grands Genies de la Peinture qui sont celebrer en ce livre). ${ }^{22}$ Thus he neatly resolves his dilemma. In fact, she does not belong in this gallery of great scholars and artists. Nevertheless, in appreciation of her qualities, both as a mother and as an artist, he feels justified in bestowing upon her a modicum of praise. It is also remarkable that he uses the word industrie, or diligence, to summarize her artistic activities, as if to stress that his mother had been merely a dilettante. ${ }^{23}$

22 Annotated Manuscript of Académie des Sciences et des Arts, MS 819, f. 413, Lille, Municipal Library: “L'estime que l'on fait des Peintures d'Anna Françoise de Bruyns merite bien que je luy donne rang en cette Académie, non pour l'y faire esclater par les loüages vaines, et suspectes; mais pour rendre ce que je dois à la mémoire d'une bonne, et vertueuse Mere; qui par la tendresse avec laquelle elle m’a éslevé, et nourry de son sein ne me permet point de payer ses soins d'ingratitude, n'y de passer sous silence la renommée qu'elle a acquité par le pinceau'; 'Un enfant doit parler sobrement de sa Mere, et la loüer avec modestie.”

23 See on the terminology: Katlijne Van der Stighelen, 'Amateur Art as a social skill and a female preserve: some thoughts on amateur artists of the 16th and 17th centuries', in Delia Gaze (ed.), Dictionary of Women Artists (London: Fitzroy Dearborn Publishers, dl. 1, 1997), 66-8o; Ann Bermingham, "The aesthetics of ignorance: The accomplished woman in the culture of connoisseurship," Oxford Art Journal 16, 2 (1993): 3-20; Ann Bermingham, 
Among all the artists who are included in the printed version of the Académie, only one other woman is mentioned, and that reference is also embedded within a biography of someone else. In the entry on the French painter Simon Vouet, the only French artist in the gallery, Bullart refers to Vouet's wife, Virginie de Vezzo Vellatrano, as "a Roman Lady who was extremely beautiful and very skilled in the art of painting." 24 One gets the impression that, at least in Jacques Ignace's opinion, it was also her beauty that led to her success.

\section{$4 \quad$ A Mother as an Artist}

Given the laudatory nature of the rest of Jacques Ignace's handwritten entry on Anna Francisca de Bruyns, we might well surmise that the real point of this introduction was to gain his readers' trust and predispose them towards his mother. Once he arrives at a detailed account of her life and work, it soon becomes a compelling encomium. He begins by describing his mother's artistic talent, which was obvious even when she was a child: elle s'amusait à tracer avec l'aiguille sur l'escorce tendre de quelques arbres (she loved to trace [figures] with a needle in the soft tree bark), and some of these reliefs apparently remained in the family for a long time. ${ }^{25}$ In March 1616, when she was not yet twelve years old, she made a masterly copy of a print of Mamluke horsemen by Jan Swart

Learning to draw. Studies in the cultural history of a polite and useful art (New Haven/ London: Yale University Press, 2000); Philippe Bourdin, "Un public d'amateurs dans la France moderne?" in Les divertissements utiles des amateurs au XVIII siècle, (ClermontFerrand 2000), 87-108.

24 Isaac Bullart, II, 492. See also: Michèle-Caroline Heck, L'histoire, 75: “(...)'Dame Romaine d'une beauté singulière, \& si bien instruite en l'Art de peindre, qu'elle eut souvent l'honneur de travailler en la presence du Roy, \& de recevoir de sa bouche les loüanges qui estoient deüs aux ouvrages de sa belle main."

25 MS 819, fol. 414, Lille, Municipal Library: “(...) si est-ce que l'on a gardé quelques unes de ces escorches dans la famille comme une rareté , aussy longtemps que les traits de sa main y ont paru." It is surprising to learn that making small reliefs was one of the initial artistic techniques pursued by women of the upper or middle class. Also Anna Maria van Schurman reports in her autobiography that she carved small portraits in wax, alabaster and boxwood. See: Katlijne Van der Stighelen, "'Et ses artistes mains ...' The Art of Anna Maria van Schurman," in Choosing the better part. Anna Maria van Schurman(1607-1678), Archives Internationales d'Histoire des Idées/International Archives of the History of Ideas, 146, eds. Mirjam de Baar, Machteld Löwensteyn, Marit Monteiro en Agnes A. Sneller (Dordrecht-Boston-London, 1996), 55-68; Desmond M. Clarke, "Anna Maria van Schurman and women's education," Revue philosophique de la France et de l'étranger, 138, (2013): 347-360. 


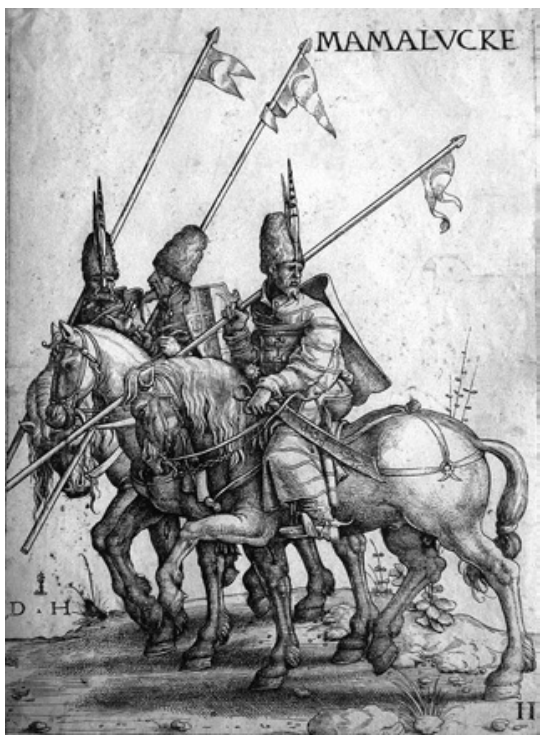

FIGURE 6.7

Jan Swart van Groningen, Three

Mameluk Horsemen, 1526, The

Metropolitan Museum of Art, New York

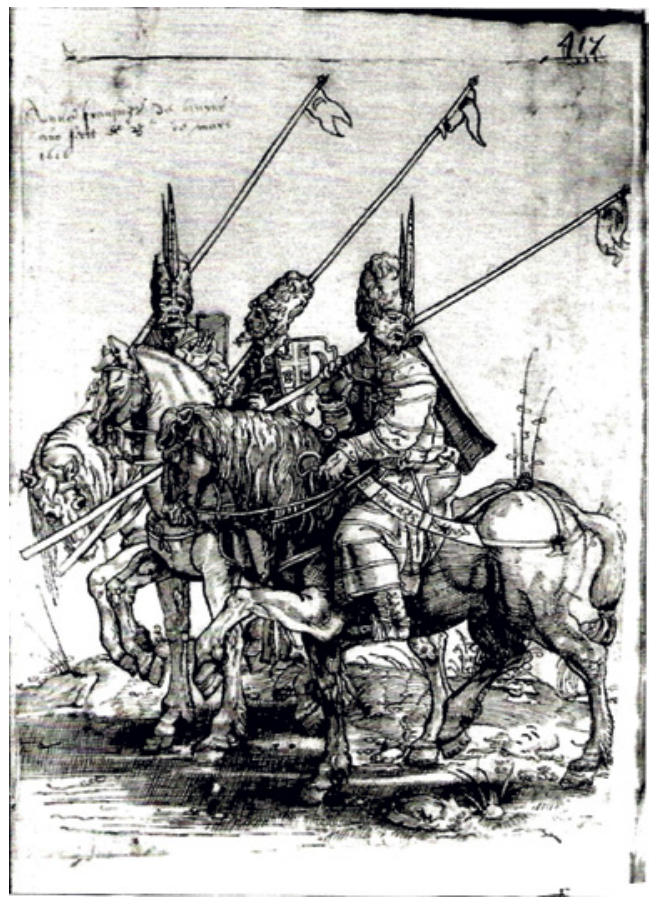

FIGURE 6.8

Anna Francisca de Bruyns after Jan Swart van Groningen, Three Mameluk Horsemen, 1616, MS. 819, f. 417, Bibliothèque Municipale, Lille 
van Groningen (1500-c. 1560), dated $1526 .{ }^{26}$ The drawing, a rather unexpected subject for a young girl, is signed and dated at top left: Anna Fransoize de bruijns an(n)o fecit le 25me de mars 1616, although she left out van Groningen's caption, MAMALVCKE. ${ }^{27}$ The young De Bruyns also made pen and ink copies of images of the Virgin and other pious prints. ${ }^{28}$ Copying drawings by earlier masters was part of the education of every pupil with artistic ambition and in many cases preceded training in the artist's workshop. ${ }^{29}$

Once she had acquired cette habitude au desseing (this skill in drawing) she was sent to Brussels to "polish her skills" (de pouvoir polir) under the guidance of her cousin Jacques Francart. He took his tutoring seriously and it was not long before Anna was proficient enough to handle the brush. In 1622 - at the age of seventeen - she made a portrait of Francart on a silver plate. Here, Jacques Ignace notes in the margin that it is the same one that you see in

26 The drawings are inserted (glued) in the manuscript by Isaac Bullart for his 1682 posthumously published book Académie des Sciences et des Arts, part 3, preserved in MS 819 , f. 417 , Lille, Municipal Library.

27 MS 819, fol. 417, Lille, Municipal Library. In the margin J. I. Bullart added 'Les trois Persans sont à la page suivante', where indeed the drawing has been glued into the manuscript.

28 MS 819, fol. 414, Lille, Municipal Library: “(...) elle s'amusait (...) avec la plume sur le papier, des figures qu'elle tiroit apres les images de la Sainte Vierge, et autres de Piété (...)." Exactly the same remark has been made related to the young Anna Maria van Schurman: "Lan 1620 Elle commenca de son propre mouvement a reprendre le crayon, pour copier quelques pièces d'excellens maistres, que son père avoit dans ses sales, et ayant veu les ouvrages de certain Hoefnagel, qui estoit tres bon peintre en miniature, elle eut l'inclination de l'jmiter, et demanda qu'on luy fournit de couleurs." See: Katlijne Van der Stighelen, Anna Maria van Schurman (1607-1678) of 'Hoe hooge dat een maeght kan in de konsten stijgen' (Leuven, 1987), 92-93.

29 A unique example of copying after antique sculpture or paintings, drawings or engravings from older and contemporary masters (e.g. sixteenth-century prototypes) is given by Rubens. See: Marjon van der Meulen, Rubens Copies after the Antique, Corpus Rubenianum Ludwig Burchard XXIII (London: Harvey Miller, 1994); Kristin Lohse Belkin, The Costume Book, Corpus Rubenianum Ludwig Burchard XXIV (London-Philadelphia: Harvey MillerHeyden \& Son, 1978), esp. 23-31; Kristin Lohse Belkin, Copies and Adaptations from Renaissance and Later Artists. German and Netherlandish Masters, Corpus Rubenianum Ludwig Burchard XXVI (1) (London: Harvey Miller, 2009); Jeremy Wood, Copies and Adaptations from Renaissance and Later Artists. Italian Artists, Corpus Rubenianum Ludwig Burchard XXVI (2.1-3), 3 volumes (London: Harvey Miller, 2011).- On the practice of women particularly, see: Kim Sloan, 'A Noble Art.' Amateur artists and drawing masters c. 1600-180o, exhibition cat. (London: British Museum, 2000). In the sketchbook another copy after a sixteenth-century, probably Italian, and not yet identified painting is included. The scene depicting Mary and Elizabeth with Jesus and the infant John the Baptist was copied hastily with rather slapdash lines in black ink. See: Sketchbook of Anna Francisca de Bruyns, inv. no. 6507, fol. 17, black ink on paper, $140 \times 201 \mathrm{~mm}$, Brussels Royal Library Print Room. 
this book (Fig. 6.3), adding that he had received the etching from his father. ${ }^{30}$ The print is actually present, tucked into the manuscript, its Latin caption describing Jacques Francart as painter to the archdukes and De Bruyns' teacher (Discipula sua). ${ }^{31}$ It was only in 1648, 26 years later, that the portrait was etched by Wenceslaus Hollar for inclusion in the Académie des Sciences et des Arts. ${ }^{32}$ Francart was so impressed by Anna Francisca's portrait of him that he showed it to the archduchess, who extolled une fille digne de sa connaissance, et de son estime (a girl worthy of her renown and others' respect). Then follows the story of the fifteen Mysteries of the Rosary paintings that were given to Pope Paul $v$ as a gift. Given Paul v's death in 1621, that date serves as a terminus ante quem for the execution of the series. It seems that in a very short time Anna Francisca had found her niche at court. Jacques Ignace writes that in that period she "exercised her brush in the house of Francart in Brussels" (exerçoit son pinceau en la maison de Francart, à Bruxelles). ${ }^{33}$ The young woman, who was not yet twenty, had been fortunate enough to leave Mons to be trained by her cousin in the capital.

According to her son it was in Francart's house that Isaac Bullart began to court her, charmed as much by the beauty of her art as by the loveliness of her face. ${ }^{34}$ He tried to win her by offering her "his services" (ses services). Despite his best efforts it was not all smooth sailing: "it was not easy for him to engage her because she tended to be more retiring than social, more inclined to the cloister than to the world." 35 Yet finally, Anna Francisca de Bruyns agreed to be guided by her confessor and parents and consented to marry Isaac Bullart. ${ }^{36}$ On 30 May 1628 they were wed in the Church of Saint-Germain in Mons. ${ }^{37}$ A year later she followed him to Arras, where on 23 April he had been named the superintendent of the Mount of Piety - an honourable and lucrative

$30 \quad$ "C'est le même que l'on voit en ce livre".

31 MS 819, fol. 414, Lille, Municipal Library: "A l'age de dix-sept ans elle fit en petit sur une lame d'argent le portrait du mesme Francquart, qui m'a esté donné par mon père, et que Hollar a gravé à l'eau forte."

32 See: F. W. H. Hollstein, Dutch and Flemish Etchings, Engravings and Woodcuts, ca. 1450170o, vol. 7, (Amsterdam, 1952), 11; F. W. H. Hollstein, vol. 9 (Amsterdam, 1953), 71. Etching, $155 \times 100 \mathrm{~mm}$.

33 From 1613 onwards Francart lived in Brussels. See: Annemie De Vos, 20-21.

34 Ibid.: “(...) que espris de la beauté de son art, aussy bien que celle de son visage (...)." See also not 18 where the same remark has been made for Virginia da Vezzo.

35 Ibid.: "mais il ne put l'engager facilement, à cause qu'elle avoit plus d'inclination pour la retraite que pour la compagnie, pour le cloistre que pour le monde."

36 See also above, note 3 , for the reference to Schurman's advice to educated women not to marry.

37 Ibid. 


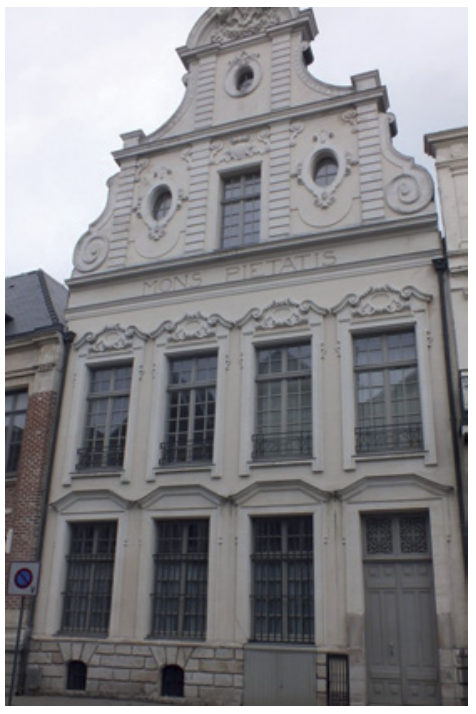

FIGURE 6.9

Wenzel Cobergher, Mount of Piety of Arras, 1624

appointment, Jacques Ignace assures us. Two weeks earlier, in Mons, Anna Francisca de Bruyns had given birth to a son, whom they named Wenceslas. There was nothing random about this choice of name, for it was thanks to Wenceslas Cobergher that Isaac Bullart had been given the job in Arras, and he was also the architect of the Mons Pietatis, the splendid new house in which they were to live. The child, his namesake, died in infancy. ${ }^{38}$ According to Jacques Ignace's account, however, the couple would ultimately have twelve children together. ${ }^{39}$

\section{5}

\section{A Wife as a Virgin}

Jacques Ignace reflects on the changes in Anna Francisca's life: "After her marriage it became much more difficult for her to find time to practice her art. Although she lamented it, taking care of her large family frequently forced her to put down her paintbrush." In spite of these responsibilities, she still managed to draw and paint after her marriage. Jacques Ignace mentions twelve portraits of "virgins ... that she painted from life after the most beautiful faces in the city of Arras." One of them was a self-portrait as a St. Susanna, in which she followed a long tradition of women artists painting self-portraits with the

$38 \quad$ Mieke Ackx (note 1), 18. He was baptized in the Curch of St. Germain on 7 April 1629.

39 MS 819, fol. 415, Lille, Municipal Library. 
help of a mirror. ${ }^{40}$ Jacques Ignace's admiration is heartfelt. His mother cleverly organized her various responsibilities so as to leave herself time for painting.

Enlisting local models on the basis of their beauty, as De Bruyns apparently did, recalls an anecdote from Pliny's Historia Naturalis. The story tells of how the ancient Greek painter Zeuxis set about portraying Helen of Troy. In order to make her as stunning as possible, he chose the five most beautiful women in Agrigentum and selected the best feature from each of them to arrive at a portrait of the ideal woman. ${ }^{41}$ It is intriguing that Anna Francisca chose to portray herself as St. Susanna, an early-Christian martyr who refused to marry Emperor Maxentius because she wished to remain a virgin. Was this a reference to her own initial desire not to marry? ${ }^{42}$

Nor did Anna Francisca's cleverness end there. The idea she devised for the cycle of virgins was also exceptional. To produce the virgins' likenesses, she arranged for some of the townswomen of Arras to sit for her. She included herself among the twelve. There is a whole tradition of women painting selfportraits with the help of a mirror. Yet to paint oneself without a mirror requires additional skill, not to mention great familiarity with one's own face. ${ }^{43}$ Unfortunately, these twelve paintings do not seem to have survived.

It is hard to imagine what these portraits historiés of twelve virgins would have looked like, but an engraved self-portrait provides an indication. Its inscription states that Anna Francisca painted the (now untraced) prototype in

$40 \quad$ MS 819, fol. 414-415, Lille, Municipal Library: "Dans ce changement de condition il luy fut difficile de conserver tout le temps qui luy estoit necessaire pour l'exercice de son Art. Les soins qu'une femme est obligée de prendre de sa famille luy osterent souvent le pinceau de la main, quoy qu'à son regret'; 'qu'elle prit du naturel sur les plus beaux visages de la ville d'Arras; parmy lesquels elle fit le sein propre hors d'un miroir, representant saincte Susanne." On women artists painting their self-portrait, see: Joanna Woods-Marsden, Renaissance Self-Portraiture. The Visual Construction of Identity and the Social Status of the Artist (New Haven-London: Yale University Press, 1998), 187-222; Frances Borzello. A World of Our Own. Women as Artists (London: Thames \& Hudson, 2000), 166-193.

41 See: Pliny, Natural History, Chapter 36: "And yet, so scrupulously careful was [Zeuxis], that on one occasion, when he was about to execute a painting for the people of Agrigentum, to be consecrated in the Temple of the Lacinian Juno there, he had the young maidens of the place stripped for examination, and selected five of them, in order to adopt in his picture the most commendable points in the form of each."

42 As to Anna Francisca's twelve paintings it is unlikely that any have survived.

43 On women artists painting their self-portrait, see: Joanna Woods-Marsden, Renaissance Self-Portraiture. The Visual Construction of Identity and the Social Status of the Artist, New Haven-London, 1998, pp. 187-222; Frances Borzello. A World of Our Own. Women as Artists, London, 2000, pp. 166-193. 


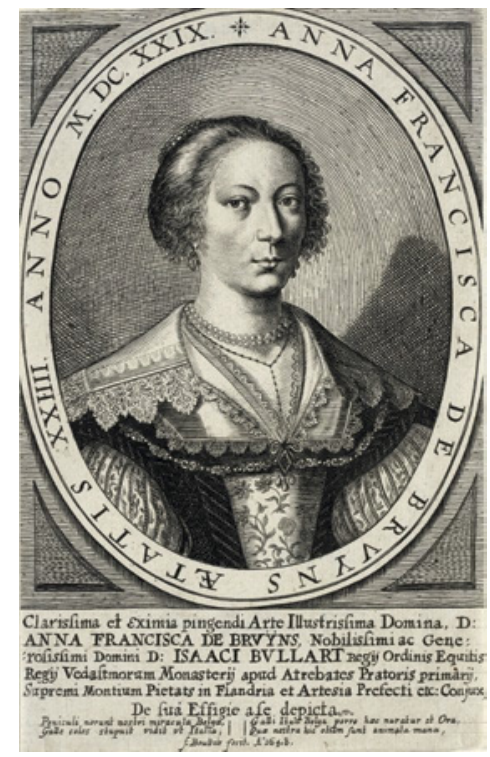

FIGURE 6.10

Frederik Bouttats after Anna Francisca de Bruyns, Self-Portrait, engraving after the prototype of 1629 , 1648, MS. 819, f. 633, Bibliothèque Municipale, Lille

1629 when she was twenty-four years old (De sua Effigie a se depicta). ${ }^{44}$ The engraving was executed only in 1648 , by two different engravers, Wenceslaus Hollar (Fig. 6.2) and Frederik Bouttats (Fig. 6.10). In the engraving, Anna Francisca de Bruyns looks out from the image, an indication that she used a mirror for this early self-portrait. Since the portrait is perfectly in keeping with the other portraits in the Académie des Sciences et des Arts, we can assume that this picture of Anna was also meant to be included in that compendium, and the two versions of the print have indeed been added to the Lille manuscript, signed in full and dated. ${ }^{45}$ At a later point, however, Jacques Ignace seems to have changed his mind about including his mother's portrait in the Académie and the engraving was never published.

44 As the portrait of Jacques Francart engraved by De Bruyns in silver, her self-portrait was also engraved by Wenceslaus Hollar (See note 24). To emphasize the fact that they - as female artists - painted the portrait themselves, they added the statement 'se ipsam' or 'a se depicta', as is the case in De Bruyns' portrait. This pictorial tradition goes back to the sixteenth century, as was elucidated by Günther Schweikhardt, Boccaccio's De claris mulieribus und die Selbstdarstellungen von Malerinnen im 16. Jahrhundert', in Der Künstler Über sich in seinem Werk. Internationales Symposium der Bibliotheca Hertziana Rom 1989, ed. Matthias Winner (Weinheim: VCH, Acta Humaniora, 1992) 113-136. See also: Joanna Woods-Marsden, 201-205. According to his testimony, Jacques Ignace disposed of the little portrait used as the prototype of the engraving. (See note 46).

45 See: F. W. H. Hollstein, vol. 4, 1951, 27; Lille, Municipal Library, MS 819 (vol. 3), f. 425; MS 819 (vol. 3), f. 633 . 


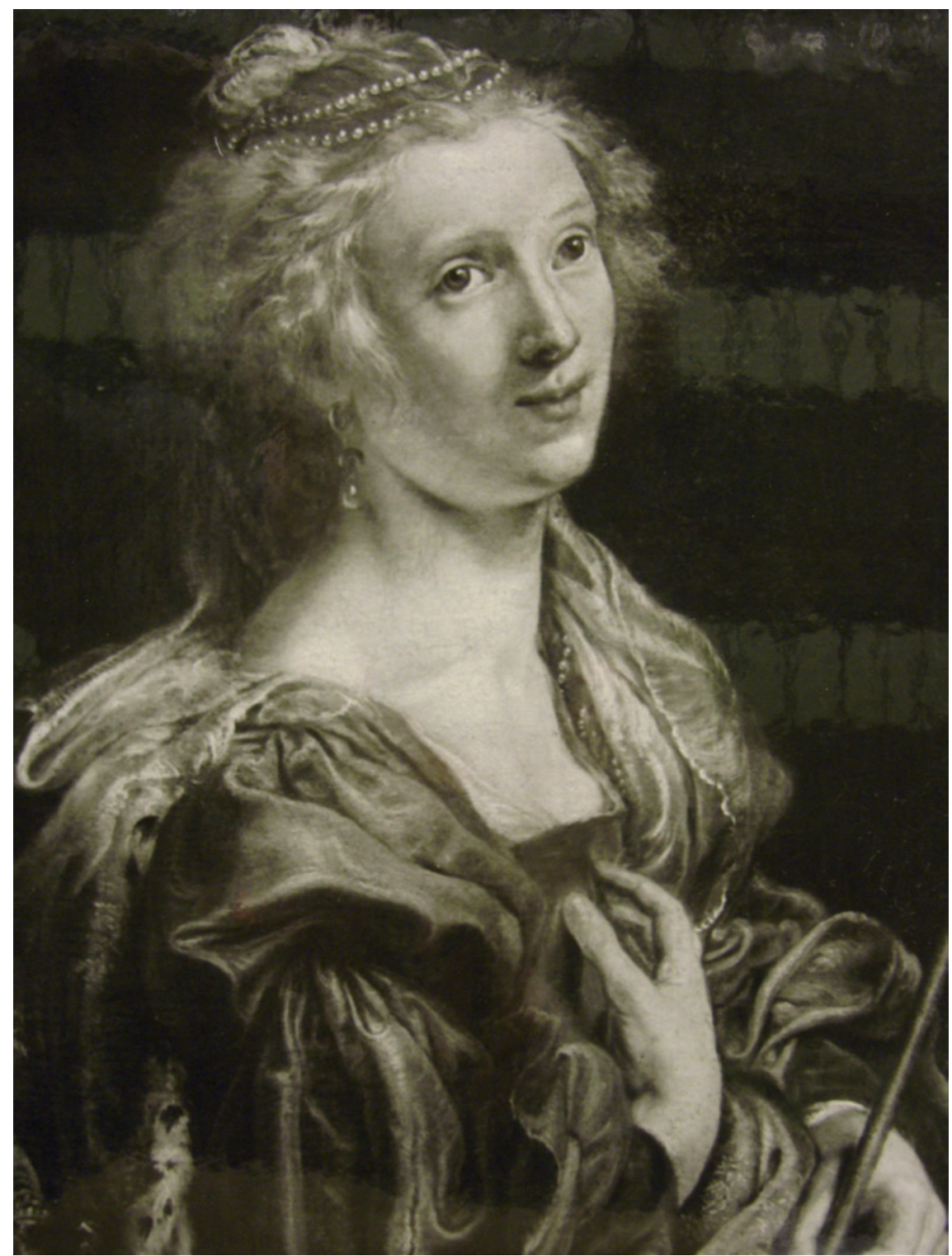

FIGURE 6.11 Anna Francisca de Bruyns, Richly Dressed Woman (possibly a self-portrait), inscribed on the back: 'A.F. de Bruyns 1633', listed in Luzern by Galerie Fischer, 11-14 May 1993, lot 2425, present location unknown

There may be a second reference to Anna Francisca in a life-sized portrait of a richly dressed young woman. Given the sitter's resemblance to her depiction in the engraving this may likewise be a self-portrait (Fig. 6.2). On the back of the canvas $(66 \times 54 \mathrm{~cm})$ is an inscription, Anna Francisca de Bruyns 1633. The 
picture is high in quality though little is known about its origin. In 1964 it was in the possession of a Parisian art dealer; it was auctioned in 1991 and again in 1993 at Galerie Fischer in Lucerne. ${ }^{46}$ This painting is just one piece of evidence that Anna Francisca continued to work as an artist after her marriage. Following his account of les Vierges d'Arras, Jacques Ignace notes that by portraying the majority of her twelve children, she gave them a second life, one far more enduring than their first (à la plus part desquels elle a donné une seconde vie par le secret de son Art, certes beaucoup plus durable que la première) ${ }^{47}$

Jacques Ignace gives some examples of Anna Francisca's portraits histories of her children in his next paragraph. Here, he suddenly jumps to his mother's final days. Towards the end of her life, he tells us, she suffered grandes afflictions de corps et d'esprit (terrible afflictions of body and mind). Jacques Ignace lays the blame for this on the intrigues and financial problems that plagued her husband in his position as Grand Bailli (Great bailiff) of the Abbey of Saint-Vaast at Arras. ${ }^{48}$ Then, just when we think the story is over, he adds an entire page listing his mother's major works as an addendum to the more biographically focused narrative, though he does not date any of them. There he mentions a Nativity in her hometown of Morialmé, mentioning that it had been completely ruined by an ignorant restorer, ${ }^{49}$ and an Assumption of the Virgin in the chapel of Notre-Dame du Bon Vouloir in Havré, a pilgrimage site near Mons. ${ }^{50}$ This last painting has survived and is hugely impressive; a sizeable canvas, it adorns the chapel's high altar. The chapel was built between 1625 and 1632 for the De Croy family, and the high altar was donated by the Archduchess Isabella in $1631 .{ }^{51}$

46 Luzern, Galerie Fisher, 5-8 November 1991, lot nr. 2360: 'Anna Francisca de Bruyns, Brustbild einer jungen Frau mit perlengeschmücktem Haar, Rückseitig signiert und datiert 1633, Oel auf Lwd, 66,5 × 54 cm'; Luzern, Galerie Fisher, 11-14 Mai 1993, lot nr. 2425 (with the same identification).

47 MS 819, fol. 415, Lille, Municipal Library.

48 See note (17) on his financial problems and lawsuits at the end of his life.

49 MS 819, fol. 415, Lille, Municipal Library: “Outre les ouvrages dontj'ay parlé elle a peint une Nativité, qui est dans une église du village de Morialmé: mais fort gastée presentement par l'ignorance d'un Peintre vulgaire qui a voulu retouchée quelques endroits que l'humidité avoit[...]".

50 Ibid.: "Elle a peint encore une Assomption que l'on voit dans l'église de Havré pres de Mons (...)." Also in the annotations in the Brussels' sketchbook is added: "Une Assomption de la Vierge qui est dans l'Eglise de Haurech près de Mons." See: Sketchbook of Anna Francisca de Bruyns, inv. no. 6507, fol. 37, Brussels Royal Library Print Room.

$5^{1}$ Havré, Notre-Dame du Bon Vouloir, high altar, canvas, $275 \times 200 \mathrm{~cm}$. For the history of the chapel, see: Pierre Vanderlinden, La Chapelle Notre-Dame du Bon Vouloir à Havré (Mons, 1982). 


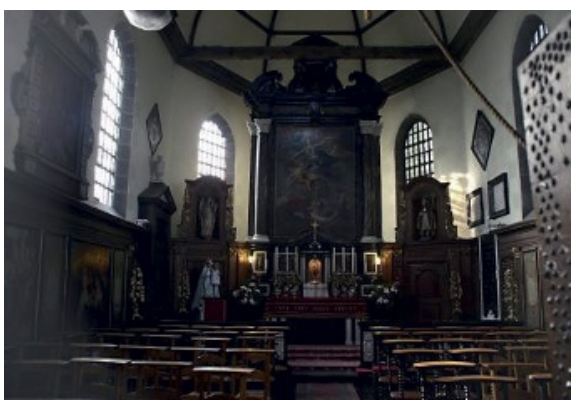

FIGURE 6.12

Chapel of Notre dame du Bon Vouloir, Havré, interior view

The archduchess undoubtedly remembered the young woman Francart had introduced to her, and she must have asked Anna Francisca to undertake the commission. The altarpiece was presumably painted shortly after the chapel was completed, which puts the date around 1631-1632. By then, Anna had been married for three or four years. According to her son she also painted the Virgin Mary with Christ and St. John as well as a picture of Mary Magdalene. Here, Jacques Ignace noted in the margin: la Vierge represent sa soeur Antoinette, le Jesus son premier enfant Venceslas" (the [likeness of the] Virgin was based on her sister Antoinette and that of Jesus on first child Wenceslas). Isaac Bullart presented the painting of the Magdalene to the Capuchin convent in Douai when his daughter Cécile became a nun there. Jacques Ignace could not resist mentioning some of the characteristics that made it typical of his mother's work: piece fort estimée pour l'action et la carnation, qui est la partie dans laquelle ma mere excelloit ([a] painting that was highly valued for the movements and complexion [of the figures], which has always been something at which my mother excelled). ${ }^{52}$ That he took good care of his mother's belongings is also evident from the next part of his manuscript, where he tells us that he kept a small self-portrait of his mother (along with a picture of his father) in a silver box, mentioning that it was this little portrait that was used as a model for the portrait engraving by Wenceslaus Hollar discussed earlier. From his summary description it is hard to be certain about the nature of the object, which may either have been a drawing or a miniature painted in oil. ${ }^{53}$

$5^{2} \quad$ MS 819, fol. 415, Lille, Municipal Library: "Elle a peint encore (...) une Vierge tenant le petit Jesus qui jouë avec Saint Jean. Une Magdelaine dans la penitence; que mon père a donnée aux Capucines Penitentes de Douai, en faveur de l'entrée de ma sœur Cécile dans leur cloistre, et quelles ont placer dans le cœur de l'église." avec celuy de mon père, et qui a servy d'original à celuy que l'on voit avec cet éloge." 
He also lists several drawings, done in chalk or pen, such as a Descent from the Cross, as well as chiaroscuro drawings on blue paper that he describes as assez curieux. The pen drawing of the Descent from the Cross is, according to his annotation in the margin, dans le livre des dessins de Rome qui est dans mon cabinet (in the book of drawings from Rome that are in my cabinet). He notes that he kept his mother's other drawings safe in his cabinet as well. ${ }^{54}$

Finally, he refers to le dernier ouvrage de son pinceau (the last work of her brush), a highly original and personal painting done in the mid-1650s when Anna Francisca once again produced a portrait historié, for which four of her children served as models: [L'ouvrage] represente quatre de ses enfants sous les figures de la Vierge, du petit Jesus, de Saint Jean Baptiste, et de Sainte Dorothée (the work depicts four of the children portraying the Virgin Mary, the infant Jesus, St. John the Baptist and St. Dorothy). Jacques Ignace mentions that she was too ill to finish it. Isaac Bullart had it completed by a skilled painter from Arras, and in 1663 he donated it to the Augustinian convent there, where another of the couple's daughters, Isabelle Sabine, was a nun. ${ }^{55}$ Jacques Ignace could not only easily identify his own brother and sisters but was also convinced that this information was important enough to make it known to later generations. At his father's request or on Jacques Ignace's own initiative, the poet Guillaume de la Rivière ${ }^{56}$ produced a Latin caption for the painting that clearly identifies exactly who is shown. On the inscription in gold letters beneath the painting, one could read that the painting was by Anna Francisca de Bruyns, an outstanding painter, wife of Isaac Bullart who installed the painting by his most beloved wife, who had portrayed her own children in

54 Ibid.: "Elle a fait encore divers desseings d'ombre et de blanc sur du papier bleu, que sont assez curieux'(...); ' L'Assomption est icy page 419 La descente de la croix est dans le livre des dessins de Rome qui est dans mon cabinet(...)." The meaning of this "livre de dessins de Rome' is not clear. Based on her son's biography, there is no evidence that De Bruyns stayed in Rome. It is not to be excluded that she kept an album in which she preserved her drawings after 'Romans' - to be red as 'antique' prototypes, either engraved or sculptured. Ibid.: "Comme elle le laissa imparfait à cause de ses infirmitez, mon père le fit achevée après sa mort par un peintre d'Arras assez entendu, et le donna au Religieuses Augustines de la mesme ville, en consideration de sa fille Isabelle, Religieuse dans leur Monastère. (...)."

$5^{6}$ Ibid.: “(...) avec cette Inscription composée par Guillaume de la Rivière, qui est en dessous en lettres d'or." Guillaume de la Rivière was the son of Guillaume de la Rivière Senior (1548after 1627) who was a nephew of Jeanne de la Rivière, wife of Christopher Plantin. The last settled in Arras from 1591 onwards as a printer and editor. His two sons, Guillaume and Jean-Baptiste, succeeded him. See: http://data.bnf.fr/12239252/guillaume_de_la_riviere/ De la Rivière Junior is the author of a manuscript in which literary works and variant notes on contemporaries have been preserved. Also a detailed biography of Anna Maria van Schurman is included. See: MS Guillaume de la Rivière, t. I, cote 69o, fol. 573, 575, t. IV, cote 694, fol. 123-130, Lille, Municipal Library; Katlijne Van der Stighelen, Anna Maria van Schurman, 10-12. 
the work: Carissima, atque eximia pingendi Arte, pergelustris Domina. Sister Isabelle Sabine is depicted as the Virgin Mary, little Cécile plays the role of Jesus, Jacques Ignace, the author of her biography, appears as St. John, and their sister, Maria-Magdalena, as St. Dorothy. All were brought to life by their mother's brush. That she depicted her offspring in such a way is a sign of her Pietatis et innocentia foemina (female piety and innocence). ${ }^{57}$ For painters to use their own children as models was not so unusual; much more extraordinary is that Anna Francisca explicitly declared it to be the case and appeared so eager to emphasize that aspect of her painting. ${ }^{58}$

A Sketch as a Fulfilment

The aforementioned Sketchbook that once belonged to Jacques Ignace Bullart in the Print Room of the Museum of Fine Arts in Brussels is only $17 \times 26 \mathrm{~cm}$ in size. The biographical information it contains is generally consistent with what we find in the Lille manuscript, and the handwriting appears to be the same. The little album contains about fifty drawings by Anna Francisca de Bruyns, which, as far as we can gather, date from different periods. It gives the impression that it was used as a "graphic diary." Besides a whole variety of sketches of heads, hands, draperies, and so forth there are many identifiable compositions in it. Most of them are sketches for religious subjects, and they show that Anna had a very conspicuous liking for scenes showing the Virgin Mary and the infant Jesus. St. Anne and St. John also make repeated appearances. There is also a preliminary study for a scene with St. Cecilia, and it is perhaps no coincidence that Anna Francisca had a daughter named Cécile. Engravings of portraits she

57 MS 819, fol. 415, Lille, Municipal Library: “(...) suos in hac Tabulâ liberos: nempe D(omi)nam Isabellam Sabinam, huiusque Monasterij Sanctimonialem sub personâ Diva Virginis Maria: Caeciliam sub imagine parvuli Jesu: filium Jacobum Ignatium sub figura S. Joannis, Agnum Jesu Matrique offerentem, et Mariam Magdalenam S. Dorothea flores offerentis(...)."

$5^{8}$ For example, the identification of Rubens's spouses and children in his history paintings has always been a point of discussion although there are some cases in which it is quite evident. On the basis of identified (drawn and painted) portraits of his children they seem to be recognizable as putti or mere children in many paintings. Of course, caution should be taken. See: Hans Vlieghe, Rubens Portraits of Identified Sitters Painted in Antwerp, Corpus Rubenianum XIX.2 (London: Harvey Miller, 1987), passim; Also Diego Velasquez and Rembrandt introduced their wives and sons as historical figures into their paintings to give only some contemporary examples. For an excellent general overview, see: Jill Berk Jiminez (ed.), Dictionary of Artists's Models, 2nd ed. (London-Chicago: Fitzroy Dearborn, 2013). 


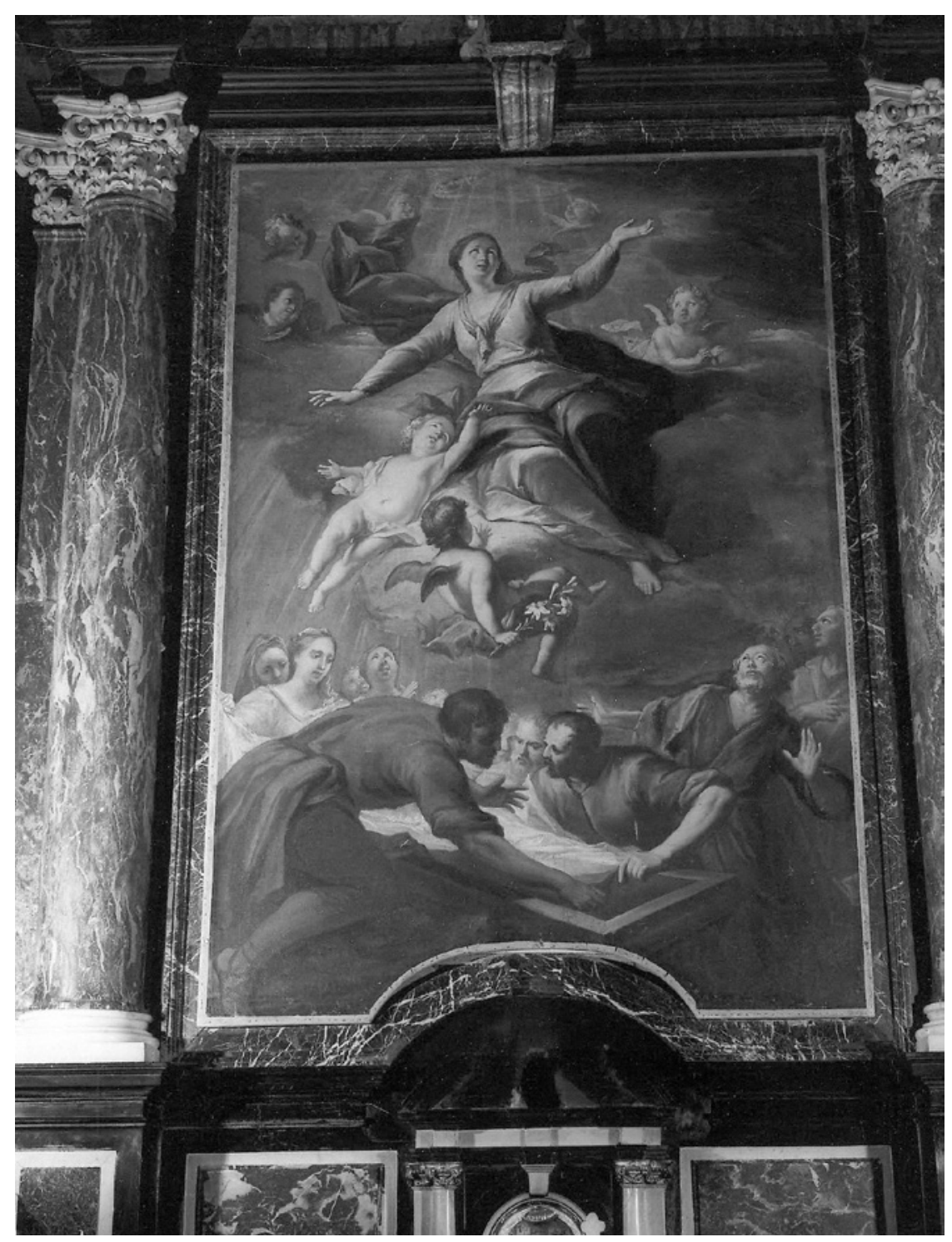

FIGURE 6.13 Anna Francisca de Bruyns, Assumption of the Virgin, high altar, Notre-dame du Bon Vouloir, Havré 


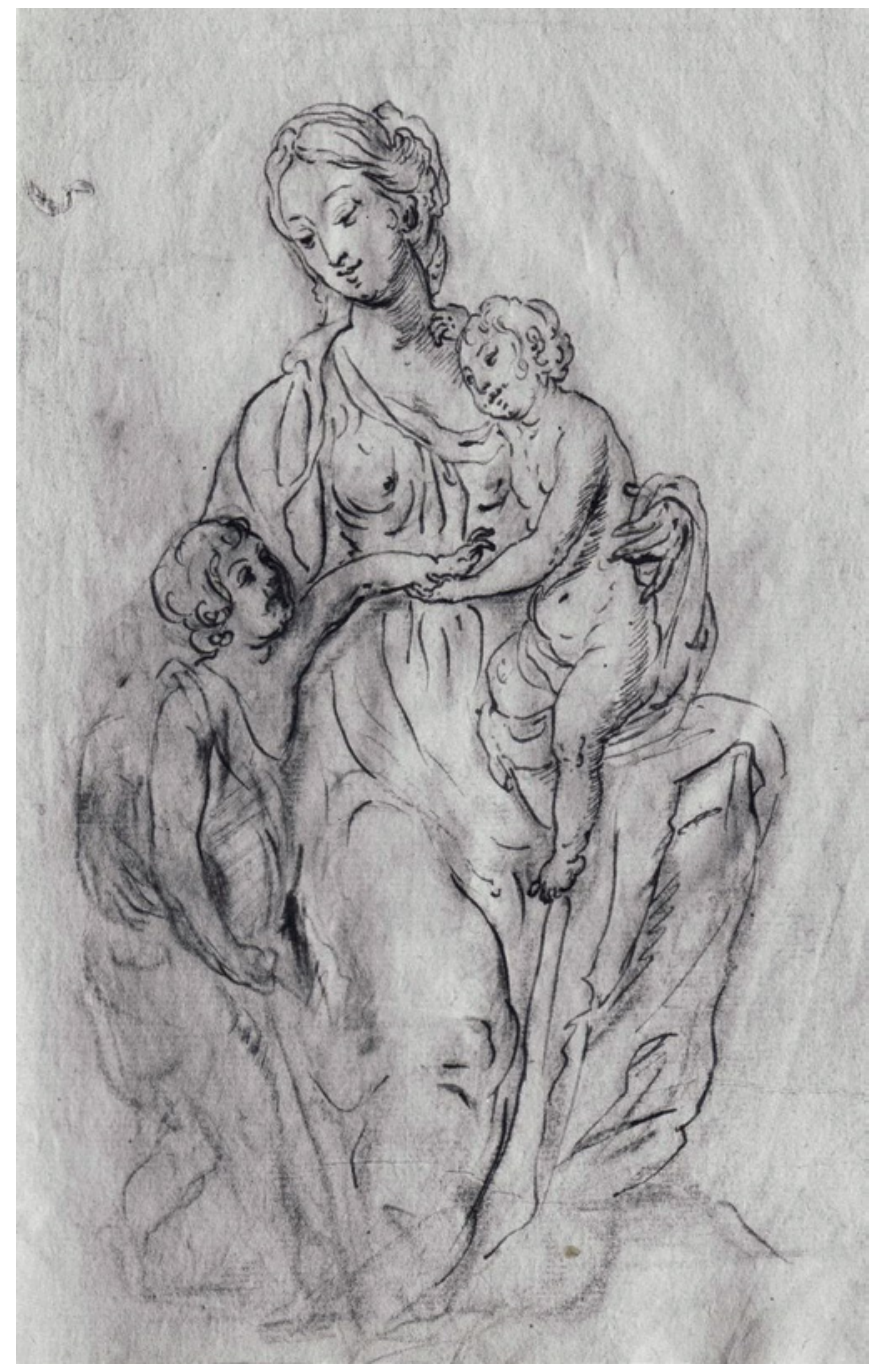

FIGURE 6.14 Anna Francisca de Bruyns, Mary, the Christ Child and St.John, sketchbook, Department of Prints and Drawings, 6507/50, Royal Museum of Fine Arts, Brussels

produced have also been included in the album. There is a single sketch for a mythological scene depicting Diana, and she twice made preliminary drawings for a painting of the The Continence of Scipio.

The album of drawings not only evinces a skillful and dynamic hand, but the prevalence of history paintings is quite striking given that during the 


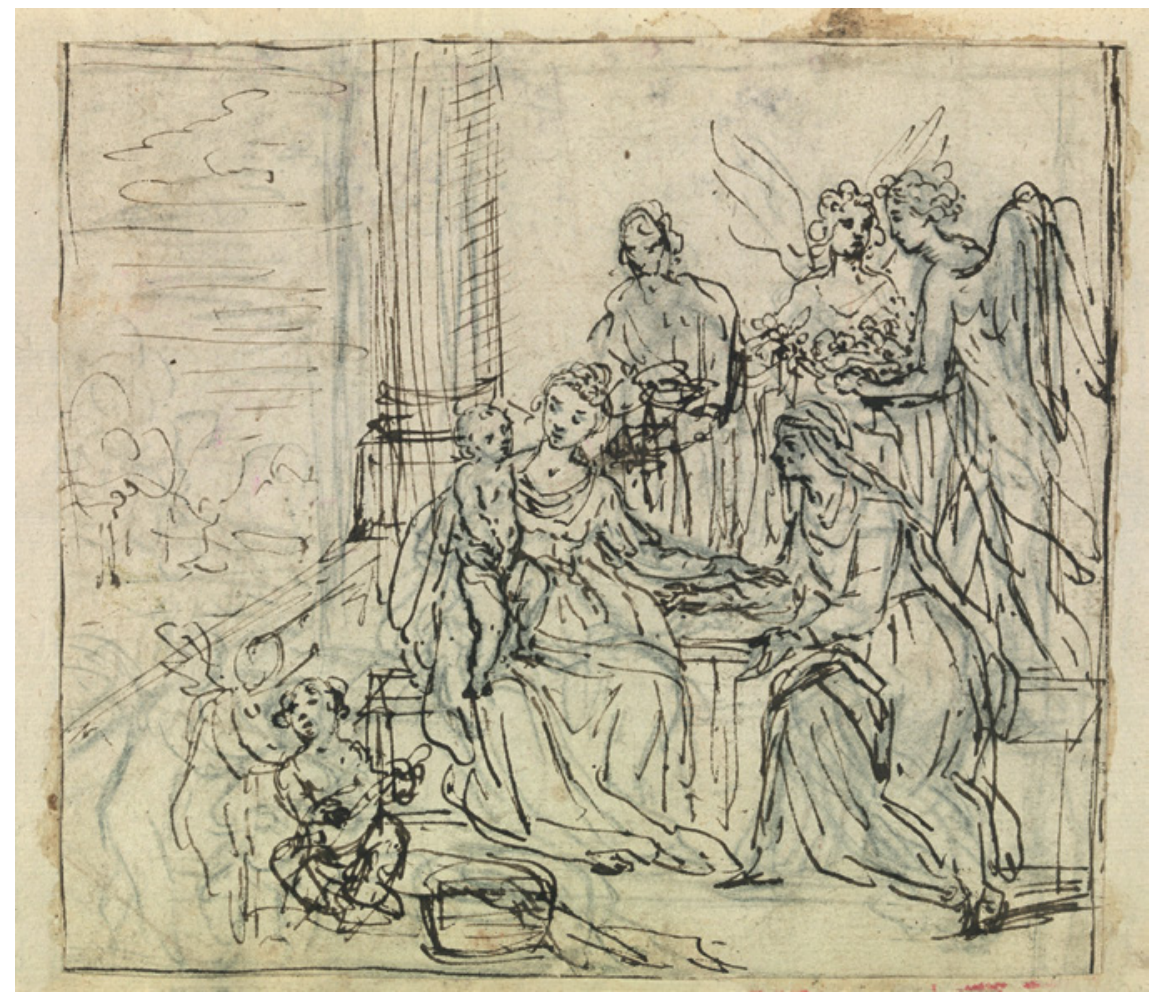

FIGURE 6.15 Anna Francisca de Bruyns, Mary, the Christ Child, and St. Anne Surrounded by Angels, sketchbook, 6507/19, Department of Prints and Drawings, Royal Museum of Fine Arts, Brussels, photo: J. Geleyns - Ro scan

seventeenth century it was so unusual for women to concentrate on such subjects. ${ }^{59}$ The fluency in rendering apparent in Anna Francisca's drawings

59 For a general introduction into the debate on the relation between social context and themes preferred by women-artists, see: Linda Nochlin, "Why have there been no great women artists? [1971]," in Women artists. The Linda Nochlin reader, ed. Maura Reilly (London: Thames \& Hudson, 2015) 42-68; In Italy a few women painters produced monumental history scenes from the late sixteenth century onwards. To name a few: Sofonisba Anguissola (c. 1535-1625), Plautilla Nelli (1524(?)-1588), Lavinia Fontani (1552-1614), Artemisia Gentileschi (1593-1654(?)) and Fede Galizia (c. 1574-c. 1630). See: Germaine Greer, The obstacle race: The fortunes of women painters and their work (New York: Tauris Parke, 1979); Italian Women Artists from Renaissance to Baroque, exhibition cat. (Washington: National Museum of Women in the Arts, 2007), 31-39, cat. Nrs. 103, 106, 135, 173, 198, 241; Frances Borzello, A World of Our Own. Women as Artists, London, 2000, 1648. Also in the Netherlands it seemed to have been exceptional. See: Els Kloek, Catherine 


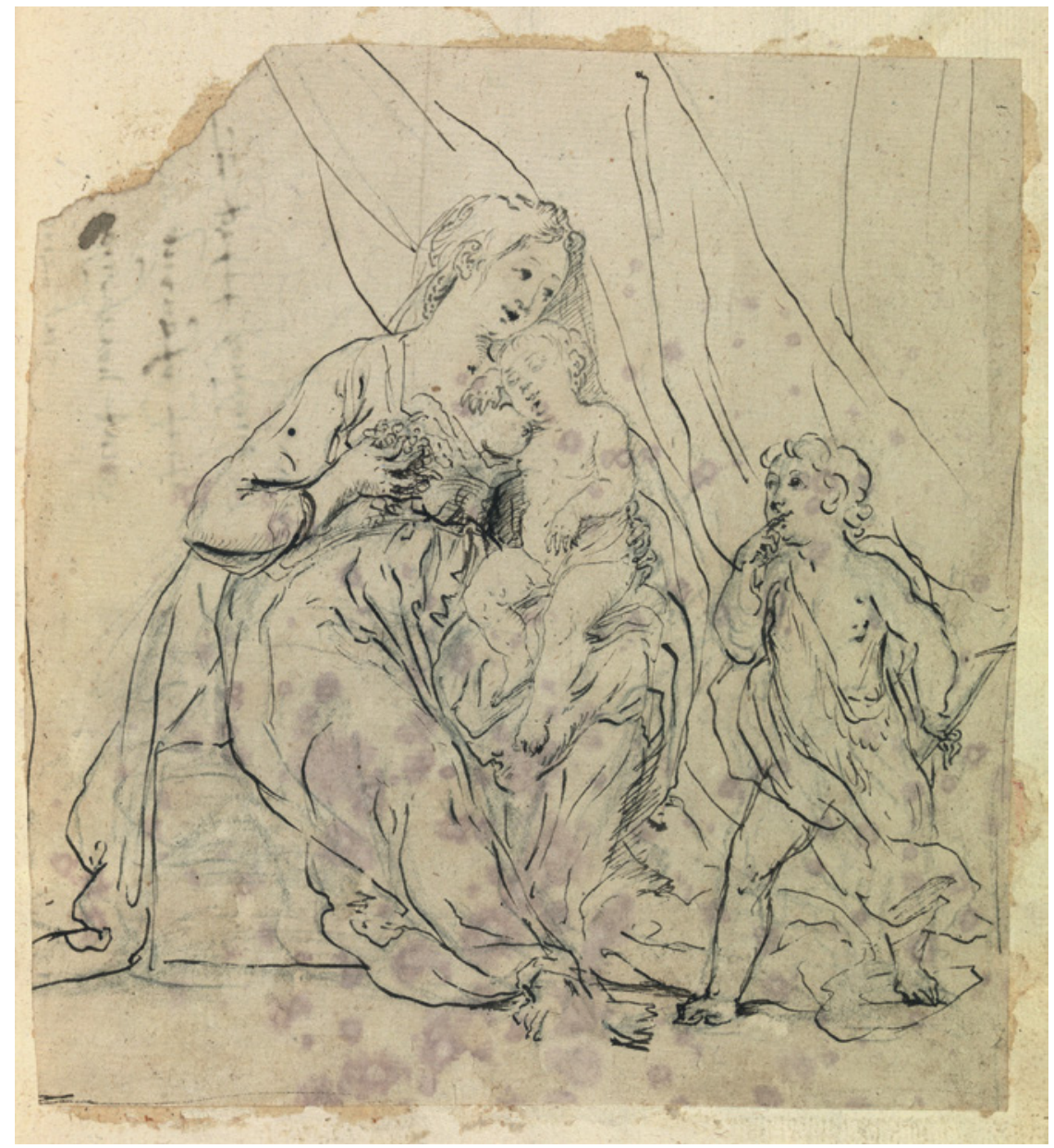

FIGU RE 6.16 Anna Francisca de Bruyns, Mary, the Christ Child and St. John, sketchbook, Department of Prints and Drawings, 6507/13, Royal Museum of Fine Arts, Brussels, photo: J. Geleyns - Ro scan

Peters Sengers and Esther Tobé (eds.), Vrouwen en kunst in de Republiek. Een overzicht (Hilversum: Verloren, 1998), 9-20. To give one example: Catharina van Hemessen painted small religious scenes of far lesser quality than her portraits. See: Karolien De Clippel, Catharina van Hemessen (1528-na1567). Een monografische studie over een uytnemende wel geschickte vrouwe in de conste der schilderyen' (Brussels: Paleis der Academiën, 2004), cat. nrs. 24-27; Marguerite Droz-Emmert, Catharina van Hemessen. Malerin der Renaissance (Basel: Schwabe, 2004). 


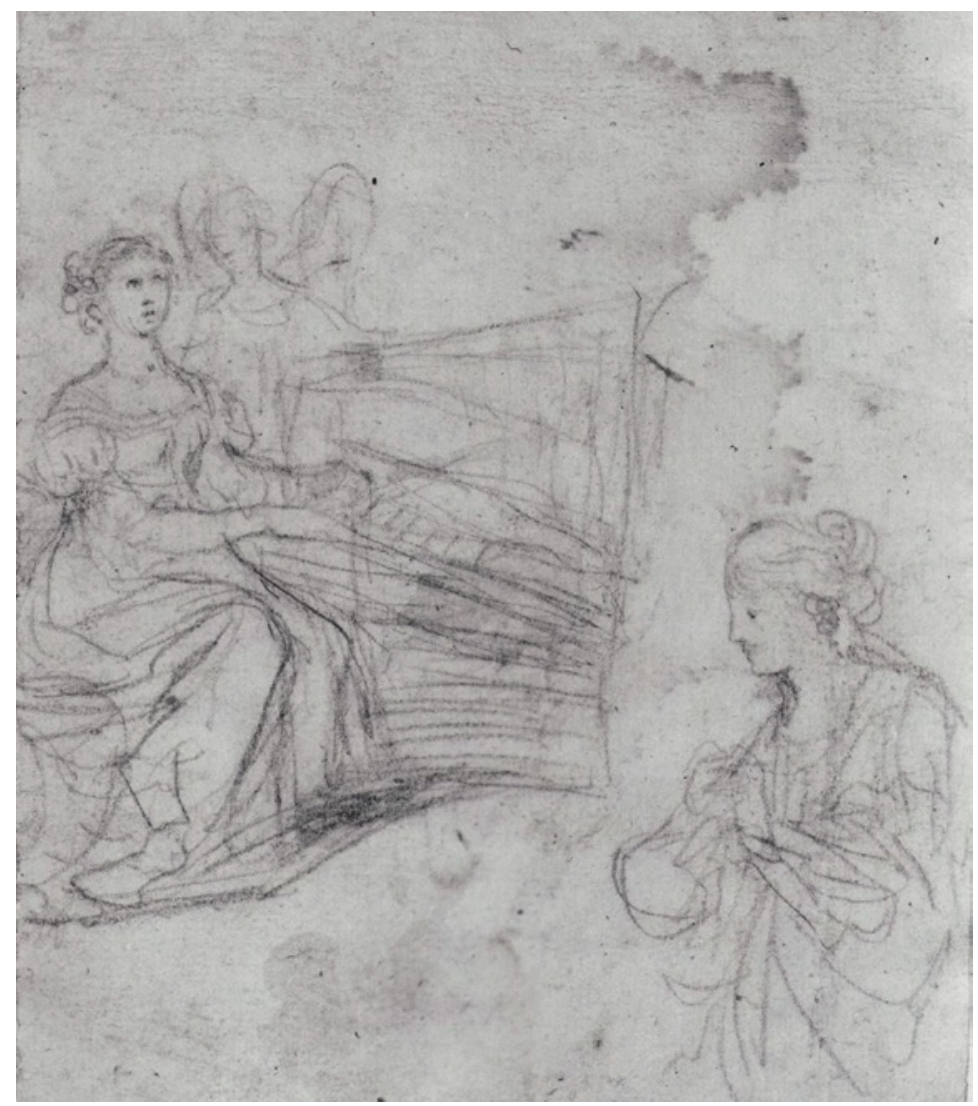

FIgure 6.17 Anna Francisca de Bruyns, St. Cecilia, sketchbook, Department of Prints and Drawings, 6507/5, Royal Museum of Fine Arts, Brussels

could only have been the result of diligent practice and knowledge of contemporary painting. ${ }^{60}$ As we saw earlier, even before she was twelve she had access to a sixteenth-century northern Netherlandish print; later on she must also have had opportunities to study and perhaps even collect paintings and prints.

6o The only woman who kept several albums that included drawings after prints and drawing books (datable c. 1720), including male nudes, is Catharina Backer (1689-1766), a daughter of elitarian parents and married to Allard de la Court, one of the main collectors in eighteenth-century Amsterdam. See: C. W. Fock, "De stillevens van Catharina Backer of de verdrijving van de melancholie," Jaarboekje voor Geschiedenis en Oudheidkunde van Leiden en omstreken, 72 (1980): 73-86; G. Sluiter, "Catharina Backer (1689-1766). Het 'bewogen leven' van een rijke dilettante," in Vrouwen en kunst in de Republiek: een overzicht, eds. E. Kloek, C. Peters-Sengers, E. Tobé (Hilversum: Verloren, 1998), 47-54. 


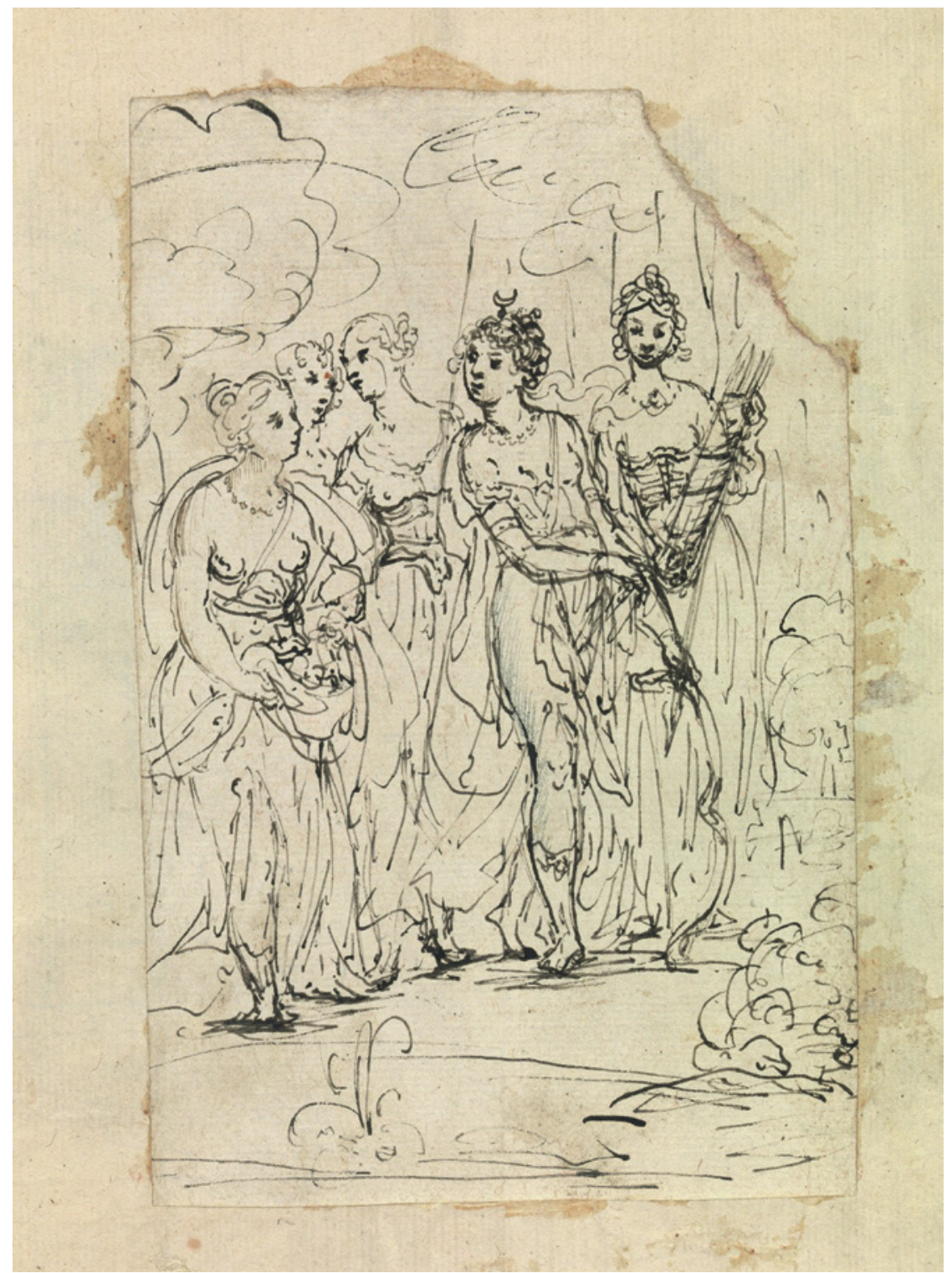

FIGURE 6.18 Anna Francisca de Bruyns, Diana, sketchbook, Department of Prints and Drawings, 6507/9, Royal Museum of Fine Arts, Brussels, photo: J. Geleyns Ro scan 


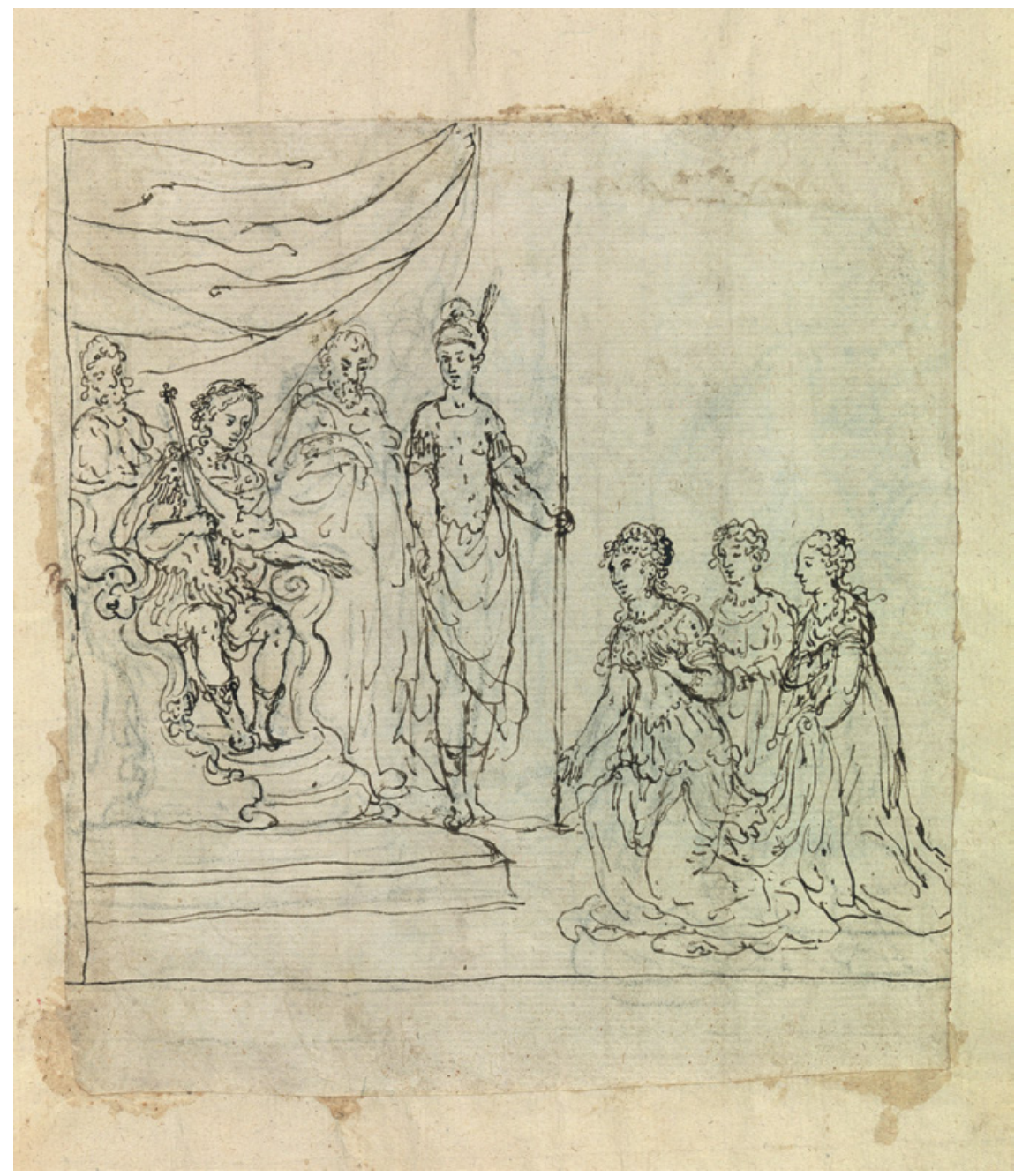

FIGURE 6.19 Anna Francisca de Bruyns, Magnanimity of Scipio, sketchbook, Department of Prints and Drawings, 6507/10, Royal Museum of Fine Arts, Brussels, photo: J. Geleyns - Ro scan

For example, she could hardly have produced her Assumption of the Virgin of around 1631 without familiarity with prints after Rubens's work of this subject, painted only a few years earlier. In addition, one wonders whether she traveled within or outside the Low Countries. ${ }^{61}$ The variety of subject matter she

61 From the biography of many middle class and upper middle class we learn that women were able to travel. There is archival evidence that merchant women uncomplicatedly 
addressed indicates that Anna Francisca de Bruyns must have had proper training. No doubt the proximity of her kinsmen Jacques Francart and Wenceslas Cobergher would have encouraged her to educate herself both intellectually and artistically. Copying after loose-leaf prints or drawing books was a standard element of early modern artistic education and enabled young artists to study the most difficult figures, animals and objects. ${ }^{62}$ If, as a young woman of only sixteen or seventeen, she went to Brussels for further training by Francart, she presumably lived in the capital for seven or eight years. Cobergher would certainly have shown her the Basilica of Our Lady in Scherpenheuvel ${ }^{63}$ (consecrated in 1627), a bastion of Baroque engineering, in which hung (and still hang) a series of paintings by Theodoor van Loon (c. 1580-1649). ${ }^{64}$

It is thanks to the care Jacques Ignace Bullart took in completing Anna Francisca de Bruyns' biography and describing her work that we have so much information about her today. His notes in the Brussels sketchbook are what

travelled from one city to another within the boundaries of The Netherlands. See: Koenraad Brosens, Klara Alen, Astrid Slegten, Fred Truyen, "MapTap and Cornelia Slow Digital Art History and Formal Art Historical Social Network Research," Zeitschrift für Kunstgeschichte, 79 (2016), 315-330 (esp. 321-325 on women in tapestry world). Single merchant women even travelled to America hoping for new trading possibilities. See: Susan Shaw Romney, New Netherland Connections: Intimate Networks and Atlantic Ties in seventeenth-Century America (Williamsburg: University of North Carolina Press, 2014), $66,75^{-79}$, 101. Also educated women had chances to travel. For example Anna Roemer Visscher travelled from the Northern Netherlands to Brussels; Anna Maria van Schurman travelled from Utrecht to Cologne, Middelburg and Amsterdam and later joined the community of the Labadists in Altona.

62 See: Victoria Sancho Lobis, "Printed Drawing Books an the Dissemination of Ideal Male Anatomy in Northern Europe," in The Nude and the Norm in the Early Modern Low Countries, eds., Karolien De Clippel, Katharina Van Cauteren \& Katlijne Van der Stighelen (Turnhout: Brepols, 2011), 51-62; Lara Yeager-Crasselt, "Knowledge and practice pictured in the artist's studio. The 'art lover' in the seventeenth-century Netherlands," De Zeventiende Eeuw, 32 (2016), 195-201.

63 On Scherpenheuvel, see: Luc Duerloo and Marc Wingens, Scherpenheuvel. Het Jeruzalem der Lage Landen (Leuven: Davidsfonds, 2002). Luc Duerloo, Dynasty and Piety: Archduke Albert (1598-1621) and Habsburg Political Culture in an Age of Religious Wars (London: Ashgate, 2012); Luc Duerloo and Werner Thomas, Albert \& Isabella. The Promise of a Golden Age. Essays (Turnhout: Brepols, 1998); Raingard Esser, The Politics of Memory. The Writing of Partition in the Seventeenth-Century Low Countries, Brill's Studies in Intellectual History (Leiden-Boston: Brill, 2012); Magdalena Sánchez, "Sword and Wimple: Isabel Clara Eugenia and Power," in The Rule of Women in Early Modern Europe, eds. Anne J. Cruz and Mihoko Suzuki (Urbana-Chicago: University of Illinois , 2009), 64-78.

64 Irene Baldriga, Brigitte De Patoul, and Marie-Françoise Dispa, Theodoor van Loon: "pictor ingenius" en tijdgenoot van Rubens, Cahiers van de Koninklijke Musea voor Schone Kunsten van België, 10 (Gent: Snoeck, 2011). 


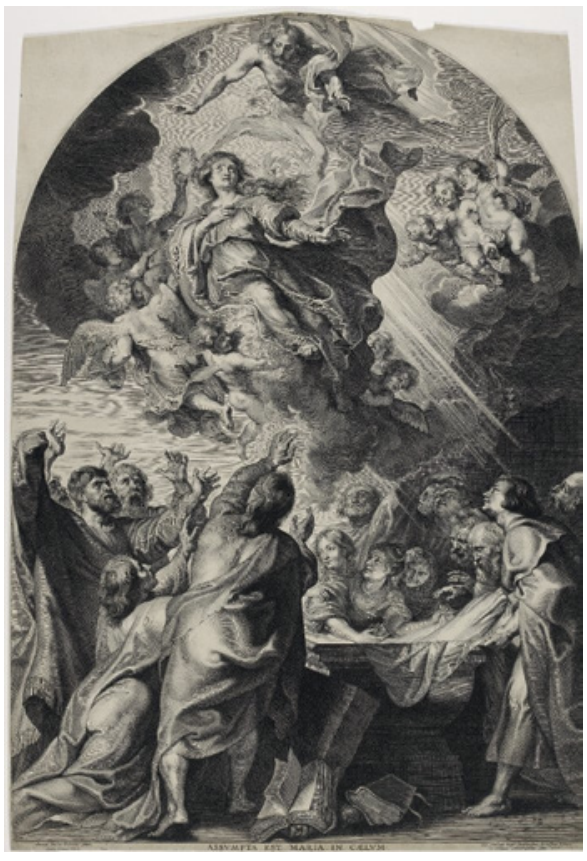

FIGURE 6.20

Paulus Pontius after Peter Paul Rubens, The Assumption of the Virgin, 1624, National Gallery of Art, Washington DC

allow us to attribute the drawings to her. Jacques Ignace was an ideal witness, but we must also remember that he was relying on his memory. His annotations were almost certainly made after his father's death in 1672 , when he began his editorial work on the Académie. By that time his mother had been dead for sixteen years. What did he remember himself and what additional sources did he use? Perhaps he consulted his brother and sisters, although by 1657 only six of the twelve children were still alive. Had their mother spoken to them about her artistic career? Jacques Ignace stressed that she had not wanted to marry, and one senses his doubt that she was satisfied with the limited time she was able to spend with a paintbrush in hand.

Her series of Twelve Virgins in Arras gives us a glimpse of her originality and ambition. As discussed above, she claimed a place for herself, disguised as St. Susanna, a move that was at once self-effacing and assertive. The engraving from 1629 has become her best-known self-portrait, even though she had to wait until 1648 before it spread via the prints that were made after it. Did she expect that her engraved portrait would figure in the gallery of brilliant scientists and artists in her husband's Académie des Sciences et des Arts? If so, who vetoed that idea? Was it Jacques Ignace himself or did Isaac make the decision after his wife's death? And how might the print relate to another "disguised" 
painted self-portrait, dated 1633, in which a beautiful woman appears in sumptuous clothing with pearls in her hair (Fig. 6.11)? The Brussels sketchbook also contains some loosely drawn self-portraits that closely resemble that painting.

One might begin to think that Anna Francisca de Bruyns maintained a consistent interest in her own image. Did she seek to balance her own "selffashioning" or focus on her own personality with scenes in which her children had the starring roles? Or did she conceive of both as somehow elements of herself? The Brussels sketchbook shows that she put particular energy into the representation of the Virgin Mary, Elizabeth and their children. It is possible that she saw these efforts as an externalization of her own maternal role and duties or that in representing her children, she sought to renounce ambition and convince herself of her own devotion and virtuousness.

Like so many Netherlandish women painters, De Bruyns did not sign her works. In spite of her sound training, however, she should perhaps be included among the dilettanti - those who made art for their own pleasure rather than as a means of gainful employment - because we do not know if she was ever paid for any of her paintings. ${ }^{65}$ It is unclear if she painted the Archduchess Isabella's Assumption of the Virgin simply for the honor or whether she was monetarily rewarded. As in the case of the fifteen small paintings that the archduchess sent to the pope, prestige was probably a greater motivation than money. ${ }^{66}$ After her marriage she sought to maintain her skills and managed to take up her brushes from time to time. The aforementioned painting from the mid-1650s shows that in this respect she succeeded almost until her death.

It is frustratingly difficult to reconstruct the lives of early modern women on the basis of archival records and literary sources. Baptism registers offer

65 See on the position of amateur artists: Katlijne Van der Stighelen, "Amateur Art as a social skill," 66-8o; Wendy Wiertz, "The rebirth of the amateur artist: The effect of past opinions on the amateur artist in current research," in Art and its responses to changes in society, in Conference proceedings: Decline-Metamorphosis-Rebirth, International conference for PhD Students, Slovenië, Ljubljana, 18-2o September 2014, Eds. Ines Unetič, Martin Germ, Martina Malešič (Newcastle upon Tyne, 2016), 63-74.

66 Prestige but also friendship relationships may have played an important role when one woman to another or men and women mutually exchanged presents such as books, engravings, miniatures in oil or pencil, cuttings, etcetera. See: L. Kooijmans, Vriendschap en de kunst van het overleven in de zeventiende en de achttiende eeuw (Amsterdam: Bert Bakker, 1997); Sophie Reinders, De mug en de kaars. Vriendenboekjes van adellijke vrouwen 1575-1640 (Nijmegen: Vantilt, 2017), 87-126. Constantijn Huygens Sr. and Anna Maria van Schurman freely offered presents to each other in order to tighten social connections and enhance intellectual pleasure. See: Katlijne Van der Stighelen and Jeanine De Landtsheer, "Een suer-soete Maeghd voor Constantijn Huygens: Anna Maria van Schurman (16071678)," De Zeventiende Eeuw: Cultuur in de Nederlanden in Interdisciplinair Perspectief, 25 (2009): 149-202. 
basic information on family matters such as birth, marriage, death and the family's parish. Occasionally residence addresses are noted, and information on godfathers and godmothers sometimes makes it possible to map a woman's social network. When women in general and artists in particular had no "official" employment, they left historians few traces to follow. However, we cannot exclude the possibility that they were fully engaged in business activities. In such cases, personal documents, including letters and accounts, can attest to their activities. ${ }^{67}$ Alba Amicora also serve as unique exponents of private culture triggered by women. ${ }^{68}$ Anna Francisca and her works only come to life thanks to the notes and preciosa her son carefully looked after, noted down and cherished. In 1718 Arnold Houbraken published De groote schouburgh der Nederlantsche konstschilders en schilderessen, a compendium in which he included a handful of women artists. Like Bullart, he also referred to Anna Francisca de Bruyns within the biography of Jacques Francart: "Anna Françoise de Bruns was a relative of his and he introduced her into the art of painting so that she exceeded all other women painters." ${ }^{69}$ At that time she was apparently still viewed as a painter of some note, but the reader was supposed to take his word for it. ${ }^{70}$

67 See: Koenraad Brosens a.o., "MapTap," $321-325$ on women acting and travelling independently in tapestry business. Another example of an extremely active and selfemployed woman is the wife of Peter Snayers, famous painter of battle scenes, living in Brussels. See: Leen Kelchtermans, "Portret van een zeventiende-eeuwse schildersvrouw: Anna Schut, huisvrouw en weduwe van Peter Snayers," in Oud-Holland, 126 (2013), 178197. Thanks to a housekeeping booklet it became possible to reconstruct her private life and social network.

68 Recent research elucidates the richness and variety of this irreplaceable medium in aristocratic society. The predictable and simple execution indicates that the ladies involved didn't intend to make a work of art but tried to enhance their social identity. See: Sophie Reinders, De mug en de kaars.

69 Arnold Houbraken, De Groote Schouburgh der Nederlantsche Konstshilders en Schilderessen, 1, 2nd ed. (The Hague, 1753), 162-163: "Anna Françoise de Bruns, die hem in maagschap bestond, heeft hy de Schilderkonst geleerd; zoo dat zy alle Schilderessen van dien tyd overtrof." Apparently Houbraken did not understand that it was De Bruyns who painted the cycle of the Mysteries of the Rosary because he noted that it was 'Francart' himself who had painted the 'Misterien' for the Archduchess and had them sent to the pope. Florent Le Comte, Het Konst-Cabinet der Bouw-Schilder, Beeldhouw-en Graveerkunde, 2 (Utrecht, 1744), 38, refers to De Bruyns adding that it was she who painted the 'Geheimenisse van de Roosekrans' for the archduchess.

70 For a wider discussion on the historiographical tradition, see: Esther Tobé, "Parels en penseelprinsessen. Kunstenaressen in drie lexica (1550-1800)," in 'Elck zijn waerom. Vrouwelijke kunstenaars in België en Nederland 1500-1950, exhibition cat. Eds. Katlijne Van der Stighelen \& Mirjam Westen (Antwerp: Royal Museum of Fine Arts, Arnhem, Gent: Museum voor Moderne Kunst, 1999), 59-67. 


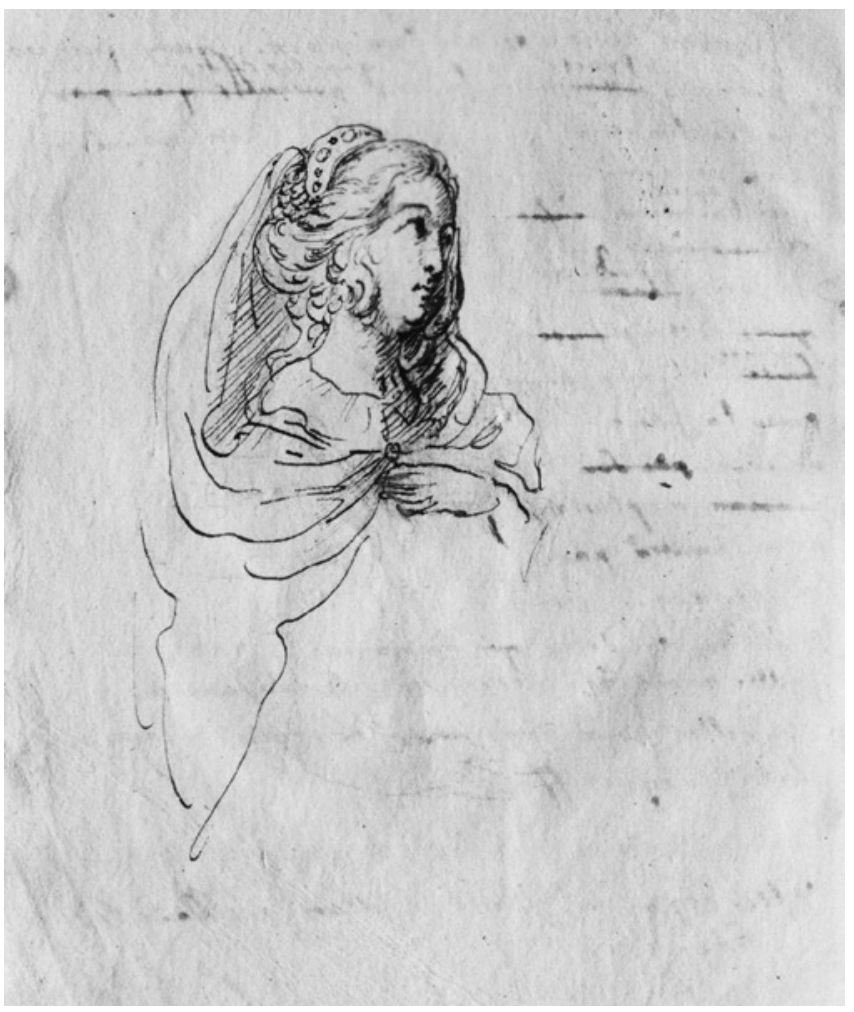

FIGURE 6.21 Anna Francisca de Bruyns, Self-Portrait (?),

sketchbook, Department of Prints and Drawings,

$6507 / 40 v^{\circ}$, Royal Museum of Fine Arts, Brussels

Just one additional contemporary sketchbook by a Netherlandish woman has been preserved, which can provide further insight into the practices of women artists at the time. Zwolle-based Geesken ter Borch, or Gesina (1631-1690), was the daughter of the painter Gerard ter Borch, and sister of Gerard Jr., Harmen and Moses, all three painters as well. She left numerous examples of calligraphy, drawings and watercolors executed in the 1660 os and 1670 . She was particularly talented at drawing and coloring small scenes of everyday life. ${ }^{71}$

$7^{1} \quad$ She left more than hundred drawings or gouaches with everyday life scenery and just a couple of historical themes such as a Joseph and the wife of Potiphar, a Nativity, S. Cecilia and The Holy Virgin. The last was drawn after a composition by Anthony van Dyck. See: Alison McNeil Kettering, Drawings from the Ter Borch Studio Estate, II (The Hague: Staatsuitgeverij, 1988), 316-76o. 


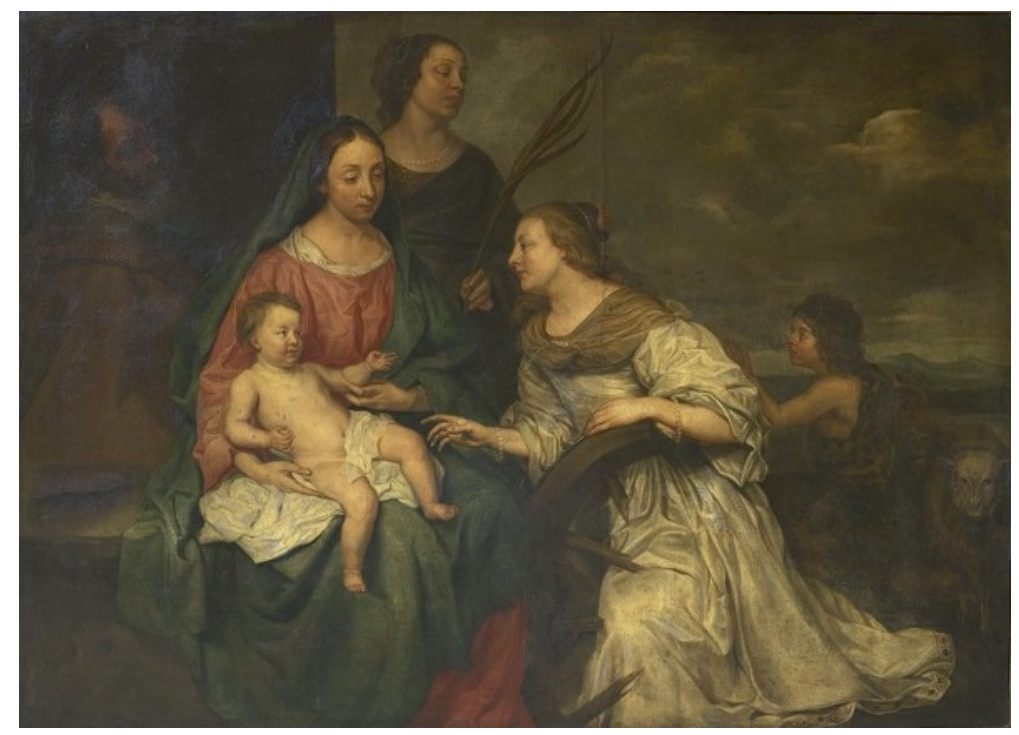

FIGURE 6.22 Michaelina Wautier, The Mystic Marriage of St. Catherine, c. 1649, Grand Séminaire, Namur

Although she would not have known it, De Bruyns almost certainly became a role model for another woman artist, Michaelina Wautier (1614-1689). Born in Mons, Wautier was fourteen when Anna Francisca married Isaac Bullart in the same city in 1628. Anna Francisca's eldest son Wenceslas was christened in the Church of Saint-Germain in Mons, the same parish church in which Michaelina's older brothers were baptized. The De Bruyn and Wautier families both belonged to the city's upper class. From the Rue d'Havré, in which Michaelina Wautier lived between 1614 and around 1640, it was only about five $\mathrm{km}$ to the Chapel of Notre-Dame du Bon Vouloir, where Anna Francisca's painting adorned the high altar (Fig. 6.13). It is therefore likely that Wautier, the only female painter of large-scale historical scenes in the seventeenth-century Low Countries, knew the painting and knew it to have been made by a woman.

Wautier had no children and no one to preserve her memory. All that remains are her signed paintings, which are even more impressive and ambitious than Anna Francisca's. Whether they were personally acquainted or not, Anna Francisca must have functioned as a role model for Michaelina, who was exactly ten years her junior. Some twenty years later Michaelina Wautier 


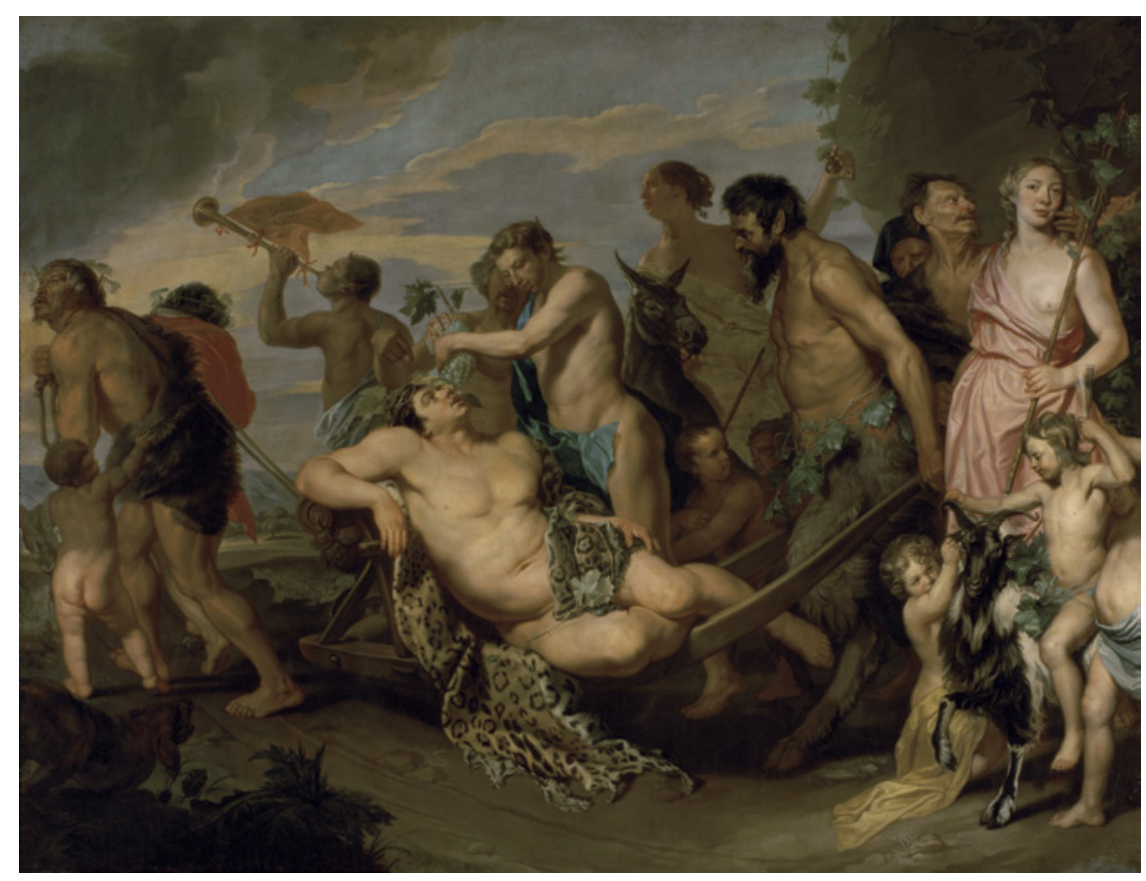

FIGURE 6.23 Michaelina Wautier, Triumph of Bacchus, c. 1655, Kunsthistorisches Museum, Vienna

painted a monumental Mystical Marriage of St. Catherine $1655^{72}$ and her daring in employing complex iconography in her drawings and paintings put her on the path to painting a monumental Bacchus procession, which entered the collection of Archduke Leopold Wilhelm around $1655 .{ }^{73}$ Although this is not the place to discuss Michaelina Wautier further, it is exhilarating to see how uncovering of the life of one woman contributes to the reconstruction of the hidden history of another. ${ }^{74}$

72 P. Y. Kairis, "Foissonnement et diversité: les peintres du XVII Siècle," in Un double regard sur 2000 ans d'art wallon (Tournai, Belgique: Renaissance du Livre; Brussels: Crédit Communal, 2000).

73 See: Katlijne Van der Stighelen, "Prima inter pares. Over de voorkeur van aartshertog Leopold-Wilhelm voor Michaelina Woutiers" in Sponsors of the Past. Flemish Art and Patronage 1550-170o, Eds. Hans Vlieghe \& Katlijne Van der Stighelen (Turnhout: Brepols, 2005), 91-116; Jahel Sanzsalazar, "Michaelina Wautier y la boda de su hermano: Historia de un retrato identificado," in Tendencias del Mercado de Arte, 69 (2014), 90-94.

74 In the Summer of 2018 a first exhibition on the paintings by Michaelina Wautier was organized by the Rubenshuis in the MAs-museum in Antwerp. See: Katlijne Van der Stighelen, Michaelina Wautier 1604-1689. Glorifying a Forgotten Talent. Antwerp: Rubenshuis, 2018. 